\title{
Gevale Kalesi Kazılarında Ortaya Çıkartılan Seramiklerde Kap Formları
}

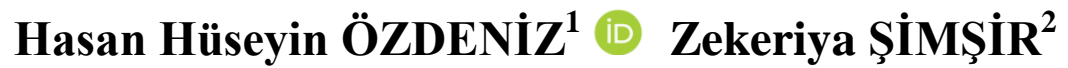

1. Uzman Sanat Tarihçi, Konya, Türkiye, hasanhuseyinozdeniz@gmail.com (Sorumlu Yazar/Corresponding Author) 2. Dr. Öğr. Üyesi, Necmettin Erbakan Üniversitesi, Sosyal ve Beşeri Bilimler Fakültesi, Sanat Tarihi Bölümü, Konya, Türkiye zsimsir@erbakan.edu.tr

\begin{tabular}{|c|c|}
\hline Makale Bilgileri & ÖZ \\
\hline Makale Geçmişi & Konya'nın batısında yer alan Gevale Kalesi tarih boyunca önemli bir savunma yapısı olarak \\
\hline $\begin{array}{l}\text { Geliş: } 26.09 .2020 \\
\text { Kabul: } 30.11 .2020 \\
\text { Yayın: } 25.12 .2020\end{array}$ & $\begin{array}{l}\text { kullanılmıştır. Zamanla büyük bir bölümü tahrip olmuş ve metruk hale gelmiş olan kalenin, yalnız temel } \\
\text { kalıntıları günümüze ulaşabilmiştir. } 2013 \text { yılından günümüze kadar devam eden kazılarda kaleye ait } \\
\text { surlar ile müşstemilatına ait çeşitli mekânlar gün yüzüne çıartılmıştır. Bu kapsamda dönemin tarihine, } \\
\text { kültürüne ve sanatına ıșı tutacak taşınabilir nitelikte malzemeler de bulunmuștur. Malzemelerin önemli }\end{array}$ \\
\hline Anahtar Kelimeler: & bir yekûnunu da genel olarak sırlı ve sırsız olarak iki gruptan meydana gelen seramikler oluşturmaktadır. \\
\hline $\begin{array}{l}\text { Konya, } \\
\text { Gevale Kalesi, } \\
\text { Seramik, } \\
\text { Selçuklu Seramiği, } \\
\text { Form. }\end{array}$ & $\begin{array}{l}\text { Kalede yapılan kazı çalışmalarında antik dönemlere ait sırsız seramiklerin yanı sıra çok sayıda sırlı } \\
\text { seramik de ele geçmiş olup, sırlı seramikler genel olarak 13. ve 15. yüzyıllar arasına tarihlendirilir. Bu } \\
\text { çalışmada } 2013 \text { ve } 2017 \text { yılları arasında Gevale Kalesi kazılarında ortaya çıkartılan seramik kapların } \\
\text { formları konu edilmiştir. Seramik kaplar; kâse, tabak, testi ve çömlek örneklerinden oluşmaktadır. } \\
\text { Günlük kullanım ihtiyacını karşılamaya yönelik üretilen bu kaplarda farklı teknik ve malzeme } \\
\text { kullanıldı̆ı görülmektedir. Kaplar formlarına göre farklı bezeme özellikleri göstermektedir. Fakat } \\
\text { çalışma kapsamında teknik ve bezeme özellikleri üzerinde durulmamış, çeşitli kap formları hakkında } \\
\text { bilgiler verilip değerlendirmelerde bulunulmuştur. }\end{array}$ \\
\hline
\end{tabular}

\section{Forms of Ceramic Vessels Founded in Gevale Castle Excavations}

\begin{tabular}{ll}
\hline Article Info & ABSTRACT \\
\hline Article History & $\begin{array}{l}\text { Gevale Castle located in the west of Konya province of Turkey was used as a predominant defence } \\
\text { structure throughout the history. Only the foundation remains of the castle, which was destroyed and } \\
\text { abandoned in time, have survived to the present day. During the excavation works that have been carried }\end{array}$ \\
$\begin{array}{l}\text { Accepted: } 30.11 .2020 \\
\text { Published: } 25.12 .2020\end{array}$ & $\begin{array}{l}\text { out in the area since 2013, the walls of the castle and various places belonging to the outbuildings have } \\
\text { been unearthed. In this context, movable materials that shed light on the history, culture and art of the } \\
\text { period were also found. A significant part of the materials consists of ceramics, which are generally }\end{array}$ \\
Keywords: & $\begin{array}{l}\text { composed of two groups as glazed and unglazed. A large number of glazed ceramics as well as unglazed } \\
\text { ceramics belonging to ancient times were uncovered during excavations in the castle, and glazed }\end{array}$ \\
Konya, & ceramics are generally dated between the 13th and 15th centuries. In this study, the forms of ceramic \\
Gevale Castle, & vessels unearthed during the excavations of Gevale Castle between 2013 and 2017 will be discussed. \\
Ceramic, & These ceramic pots involve examples of bowls, plates, jugs, and pottery. It is observed that different \\
Seljukian Ceramics, & techniques and materials are used in these vessels which are produced to meet the daily needs. These pots \\
Form. & show distinct ornamental design according to their forms. However, technical and ornamental features \\
were not included in the scope of the study, solely, information about the various vessels forms that gave & forms were provided and evaluated.
\end{tabular}

Atıf/Citation: Özdeniz, Hasan Hüseyin - Şimşir, Zekeriya. "Gevale Kalesi Kazılarında Ortaya Çıkartılan Seramiklerde Kap Formları”. Selçuklu Medeniyeti Araştırmaları Dergisi (SEMA) 5 (Aralık 2020), 59-76. https://doi.org/10.47702/sematr.2020.4

${ }^{1}$ Bu makale, Necmettin Erbakan Üniversitesi Sosyal Bilimler Enstitüsü Sanat Tarihi Anabilim Dalı'nda 2019 yılında tamamlanmış Gevale Kalesi Kazılarında Bulunan Ortaçă̆ Seramikleri başlıklı yüksek lisans tezinin bir bölümünün genişletilmiş şeklidir. 


\section{GİRIŞ}

Ana maddesi kil olan, elde, kalipta ya da tornada formu verildikten sonra firınlanan her tür eşyaya genel olarak seramik denilmektedir. ${ }^{2}$ Hamurun biçimlendirilmesi, pişirme ve sonraki kullanımlar için kırılmaması ve çatlamaması için farklı hammaddeler hamura eklenmektedir. Seramik; kuvars, feldspat, kaolin ve kilin belirli oranlarda karıştırılarak, fizikî özellikleri farklılık arz eden, pişirilmiş topraktan imal edilmiş objelere verilen genel isim olarak da tanımlanmaktadır. ${ }^{3}$ Zaman içinde keramik, seramik gibi uzmanlar tarafından farklı isimler verilmiş olsa da Türkçe'de çanak çömlek olarak da kullanılmıştır. Uzmanlar yüzeyi sırlanmış örneklere daha çok seramik adını vermişlerdir. ${ }^{4}$

Seramik, üretildiği toplumun ticarî-sosyal ilişkileri, kültürel ve folklorik unsurları yansıtması açısından önemli olduğu gibi, o toplumun seramik teknolojisindeki potansiyeli, süsleme özellikleri ve bediî sanatlarda geldiği seviyeyi de gösterir. Arkeoloji, Tarih ve Sanat Tarihi alanında gerek yüzey araştırmalarında, gerekse kazılarda ilk ele geçen buluntular seramikler olup, alanın ve kazıda katmanların tarihlendirilmesinde birincil durumdaki belgelerdir.

Neolitik çağda (M.Ö.7500-5000) seramik üretimi başlamış ve günümüze kadar gelmiştir. Tarih öncesinden günümüze kadar gelmiş olan sağlam veya kırılmış çeşitli seramik örnekleri form ve süsleme açısından tarih öncesinde yaşamış uygarlıkların yaşayış biçimlerini, sanatsal ve kültürel anlayışının yanı sıra dinî, sosyal ve ekonomik yapılarının çözümlenmesinde bize yardımcı olan önemli kaynaklardan biridir. En eski seramik örneklerine Neolitik çağa tarihlenen Çatalhöyük ve Canhasan'da rastlanmıştır. ${ }^{5}$

İslâm sanatında seramik sanatının en parlak dönemi 9.-13. yüzyıllar arasında yaşanmıştır. Halifeliğin el değiştirmesi, şehirlerin ve başkentlerin değişmesiyle çömlekçiler de çoğu kez bir başkentten öbürüne veya bir kentten diğerine taşınmıştır. ${ }^{6}$ Büyük Selçuklu dönemiyle birlikte İran'da seramik sanatı büyük bir atılım yapmış; sır altı, sırüstü, lüster ve minâî teknikleri geliştirilmiştir.

12. ve 13. yüzyıllarda İran'da Rey ve Keşan, Suriye'de ise Rakka seramikleri ile Anadolu Selçuklu seramikleri arasında paralelliklerin ve etkileşimin olduğu benzer form, teknik, renk ve süsleme özelliklerinden anlaşılmaktadır. Buna rağmen Anadolu dışında üretilen söz konusu seramikler yine form, teknik, renk ve dekor konuları bakımından daha zengin olmasına rağmen Anadolu Selçuklu seramiğinde bu kadar kaliteli örnekler görülmemektedir. ${ }^{7}$

Ortaçağda en yaygın olan sigrafitto tekniğidir. 9.-13. yüzy1llarda İslam seramikleri ile Bizans seramikleri arasında yoğun bir etkileşimin olduğu dikkati çekmektedir. ${ }^{8}$ Hatta bu etkileşim tekniğe yansımakta, bazen ortak süsleme ögeleri şeklinde de ortaya çıkmaktadır.

\footnotetext{
${ }^{2}$ Metin Sözen - Uğur Tanyeli, Sanat Kavram ve Terimleri Sözlüğü (İstanbul: Remzi Kitabevi Yayınları, 1992), 213.

${ }^{3}$ Faruk Şahin, Seramik Sözlüğ̈̈ (İstanbul: Anadolu Sanat Yayınları, 1983), 30.

${ }^{4}$ Beril Anılanmert - Zeynep Rona, "Seramik”, Eczacıbaşı Sanat Ansiklopedisi, ed. Nejat F. Eczacıbaşı (İstanbul: Yem Yayınları, 1997), 3/1634. Seramik mamüllere "keramik" teriminin kullanılmasının daha doğru olduğunu ifade eden ve konu ile ilgili terim kargaşası ile ilgili bk. Fikret Hacızade, "Seramik Alanında Kullanılan Terim ve Kavramlarda Türkçenin Durumu”, Türkiyat Araştırmaları Dergisi, ed. Hakan Kuyumcu - Çağatay Benhür (Konya: Selçuk Üniversitesi Yayınları, 2014), 45.

${ }^{5}$ Sidıka Sibel Sevim, Seramik Dekor ve Uygulama Teknikleri (İstanbul: Nonel Akademik Yayınları 2007 ), 13.

${ }^{6}$ Beril Anılanmert - Zeynep Rona, "Seramik", 3/1636.

${ }^{7}$ Gönül Öney, "Selçuklu Seramik Sanatı”, Selçuklu Çă̆ında Anadolu Sanatı, ed. Doğan Kuban (İstanbul: Yapı Kredi Yayınları, 2002), 385.

${ }^{8}$ Füsun Tülek, "Identifying Osmaniye Medieval Ceramics in Multi-Cultural Context”, XI. Alecm3 Uluslararası Orta çă̆ ve Modern Akdeniz Dünyası Seramik Kongresi Bildirileri 1(Ekim 2015), 363.
} 
Anadolu'daki Bizans yerleşimlerinin Beylikler döneminde farklı beylikler tarafindan fethedilmesiyle birlikte yerel Hristiyan seramik ustalarının üretimlerini herhangi bir inkıtaya uğramadan devam ettirdikleri bilinmektedir. Diğer taraftan buraya yerleşen Türklerin zevklerine uygun seramikler de üretmişlerdir. Selçuklu tarzı ile kendi üsluplarını sentezleyerek imal ettikleri ürünleri pazarlamışlardır. ${ }^{10}$

Anadolu Selçuklu döneminde üretilen seramiklerin form, teknik, sır ve süsleme özelliklerini Konya, Kubad Abâd, Keykubadiye, Akşehir, Kayseri, Ahlat, Samsat gibi merkezlerde yapılan kazılarda ortaya çıkartılan seramik buluntular ortaya koymaktadır.

Gevale Kalesi'nde 2013 yılında Konya Müze Müdürlüğü'nün başkanlığında, Selçuklu Belediyesi’nin maddî destekleriyle ve bilimsel danışmanlığını Prof. Dr. Ahmet Çaycı'nın yaptığı bilimsel bir heyet tarafından kazılar başlamış, 2020 yılı da dâhil olmak üzere çalışmalar devam etmektedir. Kazılarda ilk etapta Gevale Kalesi’nin kuzeyinde varlığı bilinen tapınak, önündeki avlusu, yine kuzey batısındaki potern, kaya mekânları, sarnıcın kazısı yapılarak ortaya çıkartılmıştır. Daha sonraki yıllarda zirvede çalışmalar devam etmiş, burada da onlarca sarnıç, iki hamam, şapel, kaleye ait çeşitli mekânlar bulunmuştur. Kalenin doğusunda kaya oyma mezarlar, kalenin giriş kapısı ve henüz fonksiyonu tanımlanamamış kalenin müştemilatına ait birçok mekân gün yüzüne çıkartılmıştır. ${ }^{11}$

Mimari mekânların yanı sıra çini, alçı, cam objeler, cam bilezikler ${ }^{12}$, çeşitli metal objeler, ok uçlarr $^{13}$, taş gülleler ${ }^{14}$, çeşitli dönemlere ait sikkeler ${ }^{15}$, ahşap parçalar, lüleler, mühürler ve ağırşaklar gibi malzemelerin yanı sıra bol miktarda sırsız ve sırlı seramikler de bulunmuştur. ${ }^{16}$

${ }^{9}$ Mezahir Ertuğ Avşar- Lale Avşar, Kazımall-Akıtmalı Ortaçă̆ İslam Seramikleri (Konya: Selçuk Üniversitesi Basimevi, 2014), 34-35.

10 Böhlendorf Beate Aslan, "Die Beziehungen Zwischen Byzantinischer Und Emiratszeitlicher Keramik", Ortaçă̆da Anadolu Prof. Dr. Aynur Durukan'a Armăgan, ed. N. Şaman Doğan (Ankara: Hacettepe Üniversitesi Yayınları, 2002), 135.

${ }^{11}$ Gevale Kalesi’nde yapılan yüzey araştırması, arkeolojik kazılar ve çıkan buluntular ile ilgili detaylı bilgi için bk. Ahmet Çaycı - Zekeriya Şimşir - İ. Mete Mimiroğlu, "Gevale Kalesi ve Çevresi Araştırmaları", 31. Araştırma Sonuçları Toplantısı (Muğla 27-31 Mayıs 2013) (Ankara: Kültür ve Turizm Bakanlığı Yayınları, 2014), 1/276-286; Ahmet Çaycı - Zekeriya Şimşir, "Gevale Kalesi 2013-2014 Kazı Buluntuları”, 37. Uluslararası Kazl, Araştırma ve Arkeometri Sempozyumu, ed. Adil Özme (Ankara: Kültür ve Turizm Bakanlığı Yayınları, 2016), 3/539-558; Ahmet Çaycı - Zekeriya Şimşir, "Gevale Kalesi 2014 Yılı Kazı Çalışmaları", XXII. Uluslararası Ortaçağ ve Türk Dönemi Kazıları ve Sanat Tarihi Araştırmaları Sempozyumu (Manisa 21-24 Ekim 2015), ed. Adil Özme (Ankara: Kültür ve Turizm Bakanlığı Yayınları, 2019) 1/383-401; Ahmet Çaycı - Zekeriya Şimşir, "2015 Yılı Gevale Kalesi Arkeolojik Kazısı”, Uluslararası XX Ortaçă̆ ve Türk Dönemi Kazıları ve Sanat Tarihi Araştırmaları Sempozyumu (Sakarya 2-5 Kasım 2016), Sakarya: Sakarya Üniversitesi Yayınları, 20171/37-48; Ahmet Çaycı - Zekeriya Şimşir, “Gevale Kalesi 2016 Yılı Kazı Çalışmaları", 39. Uluslararası Kazı, Araştırma ve Arkeometri Sempozyumu (Bursa, 22-26 Mayıs 2017), ed. Adil Özme (Bursa: Kültür ve Turizm Bakanlığı Yayınları, 2018), 3/251-262; Ahmet Çaycı - Zekeriya Şimşir, “Gevale Kalesi 2017 Yıı Kazı Çalışmaları”, 40. Uluslararası Kazı, Araştırma ve Arkeometri Sempozyumu (Çanakkale, 7-11 Mayıs 2018), ed. Adil Özme (Ankara: Kültür ve Turizm Bakanlığı Yayınları, 2019), 1/49-62; Ahmet Çaycı - Zekeriya Şimşir, "Gevale Kalesi 2018 Yılı Kazı Çalışmaları”, 41. Uluslararası Kazı, Araştırma ve Arkeometri Sempozyumu (Diyarbakır, 17-21 Haziran 2019), ed. Adil Özme (Ankara: Kültür ve Turizm Bakanlı̆̆ Yayınları, 2020), 1/67-77.

12 Ahmet Yavuzyılmaz, "Gevale Kalesi Cam Bilezik Buluntuları”, XX. Uluslararası Ortaçă̆ ve Türk Dönemi Kazıları ve Sanat Tarihi Araştırmaları Sempozyumu Bildirileri, ed. Ela Taş (Sakarya: Sakarya Üniversitesi Yayınlar1, 2016), 1/49-61.

${ }^{13}$ Erkan Aygör, "Konya Gevale Kalesi 2016 Y1lı Kazısında Bulunan Ok Uçları”, Türkiyat Araştırmaları Enstitüsü Dergisi 7/ 11 (Nisan 2017), 284-306.

${ }^{14}$ Ahmet Şen, "Konya Gevale Kalesi Kazılarında Bulunan Taş Gülleler”, Selçuklu Medeniyeti Araştırmaları Dergisi (SEMA) 4 (Aralık 2019), 189-224.

15 Gülüstan Ermiş, Gevale Kalesi Kazılarında Bulunan İslami Dönem Sikkeler (Konya: Necmettin Erbakan Üniversitesi, Sosyal Bilimler Enstitüsü, Yüksek Lisans Tezi, 2019). 
Bu makalede Gevale Kalesi'nde 2013-2017 y1lları arasında yapılan arkeolojik kazılarda ortaya çıkartılan Ortaçağ sırlı seramikleri ayrıntılı olarak tanıtılacaktır. Öncelikle kapların formlarının detaylı tanımları yapılacak, kısaca tekniğinden ve üzerindeki bezemeden bahsedilecek, kapların ölçüleri, profil çizimleri ve resimleri verilecek, böylelikle konu bütünüyle değerlendirilerek araştırmada varılan sonuçlar sunulacaktır.

\section{Gevale Kalesi'nin Kısa Tarihçesi}

Konya İli, Selçuklu İlçesi, Sarayköy Mahallesinde, halk arasında Takkeli dağ olarak bilinen, şehir merkezinin $10 \mathrm{~km}$ batısında, $1675 \mathrm{~m}$. yükseklikteki Küçük Gevale ile kuzey batısında $1710 \mathrm{~m}$. yükseklikte bulunan Büyük Gevale isimli iki volkanik dağ yer almaktadır. ${ }^{17}$ Araştırmaya konu olan 1675 m. yükseklikteki zirvede bulunan küçük Gevale'dir. Gevale Kalesi kaynaklarda çeşitli isimlerle anılagelmiştir. İ. Hakkı Konyalı, ismini Cybele adındaki Frig dişi yer tanrısından aldığını, bu kelimenin farklı okunması ve harflerin değiştirilmesiyle ilk zamanlarda Sibel, Sibele, olarak telaffuz edildiğini ve daha sonra bugünkü ismine yaklaştırılarak "Kevele" adını aldığını ifade etmektedir. ${ }^{18}$ Bizans döneminde Caballa ${ }^{19}$ olarak bilinmektedir. Selçuklu dönemi tarihçisi İbn-i Bibi Kaballa, Kevale ve Gevale ${ }^{20}$ olarak naklederken, diğer yayınlarda Kevele ${ }^{21}$, Kirale ${ }^{22}$, Gavele ${ }^{23}$, Kaballa ${ }^{24}$, Kevale $^{25}$, Kavala ve Kabala ${ }^{26}$ şeklinde kullanılmıştır.

Silleliler eskiden "Karaburga" şeklinde isimlendirmişler, kalenin burçları uzaktan takke gibi göründüğü için Konyalılar tarafından “Takkeli Dağ” olarak maruf olmuştur. ${ }^{27}$ Gevale Kalesi Konya’ya hâkim olan konumu sebebiyle tarih boyunca önemini hiç yitirmemiştir. ${ }^{28}$

Konya şehrinin savunması yalnız şehirdeki iç kale ve dış kale ile değil, aynı zamanda Gevale Kalesi de bu savunmaya iştirak etmekte olup, şehre yapılan saldırılar öncelikle bu kaleden karşılanmıştır. Stratejik konumu sebebiyle kaleye sahip olan Konya'ya da hâkim olmuştur. ${ }^{29}$ "Rum’un

${ }^{16}$ H. Hüseyin Özdeniz, Gevale Kalesi Kazllarında Bulunan Ortaçă̆ Seramikleri, Konya: Necmettin Erbakan Üniversitesi, Sosyal Bilimler Enstitüsü, Yüksek Lisans Tezi, 2019.

${ }^{17}$ Çaycı - Şimşir, "Gevale Kalesi 2016 Yılı Kazı Çalışmaları”, 3/251.

18 İ. Hakkı Konyalı, Abideleri Ve Kitabeleri ile Konya Tarihi (Konya: Yeni Kitap Basımevi, 1964), 164.

19 Hasan Bahar, "Takkeli Dağ (Kevele Kalesi) ve Konya Tarihi Bakımından Önemi”, S. Ü. Sosyal Bilimler Enstitüsü Dergisi 3 (1994), 313.

${ }^{20}$ Hoca Sadeddin Efendi, Tâcü’t- Tevârîh, çev. İsmet Parmaksızoğlu (Ankara: Kültür Bakanlı̆̆ı Yayınları, 1979), 1/ 511-512; Ali Sevim - Erdoğan Merçil, Selçuklu Devletleri Tarihi Siyaset, Teşkilât ve Kültür, (Ankara: Türk Tarih Kurumu, 1995), 90.

${ }^{21}$ Aşıkpaşazade, Âşık Paşaoğlu Tarihi, haz. N. Atsız (İstanbul: Milli Eğitim Bakanlığı Yayınları, 1992), 144; Konyalı, Abideleri ve Kitabeleri ile Konya Tarihi, 172-173; İ.H. Uzunçarş1lı, Osmanlı Tarihi, (Ankara: Türk Tarih Kurumu, 1972), 1/89.

${ }^{22}$ C. Huart, Mevleviler Beldesi Konya, çev. N. Uzel (İstanbul: Kervan Kitapçılık Basımevi, 1978), 108.

23 A. Şimşirgil, "Eşrefoğulları Beyliği”, Türkler, ed. Hasan Celal Güzel vd. (Ankara: Yeni Türkiye Yayınları, 2002), 6/772.

${ }^{24}$ M. Kesik, "Sultan Melikşah (Şahinşah) ve Sultan I. Mesud Dönemleri”, Türkler, ed. Hasan Celal Güzel vd. (Ankara: Yeni Türkiye Yayınları 2002), 6/558.

${ }^{25}$ Hasan Özönder, Sille (Tarih-Kültür-Sanat) (Konya: 1998), 347.

${ }^{26}$ M. H. Yinanç, “Anadolu'nun Fethi”, Türkler, ed. Hasan Celal Güzel vd. (Ankara: Yeni Türkiye Yayınları, 2002), 6/201.

${ }^{27}$ İ. Hakkı Konyalı, “Takkeli Dağ Adını Nerden Aldı", Konya Halkevi Dergisi 12 (1937), 768.

${ }^{28}$ Konyal1, Abideleri ve Kitabeleri ile Konya Tarihi, 164; Bahar, "Takkeli Dağ (Kevele Kalesi) ve Konya Tarihi Bakımından Önemi”, 313-333; Güngör Karauğuz - H. İbrahim Kunt, Eski Çă̆ Kaleleri -Orta Anadolu’nun Güney Kesimi, (Konya: Çizgi Kitabevi, 2004), 19-21.

${ }^{29}$ Zeki Atçeken, Konya'daki Selçuklu Yapılarının Osmanlı Devrinde Bakımı ve Kullanılması (Ankara: Türk Tarih Kurumu, 1998), 311; Konyalı, Abideleri ve Kitabeleri ile Konya Tarihi, 121, 835, 1163, 1167. 
Kilidi”’30 "Konya'nın Kilidi” olarak görülen yapı, Selçukluların Konya’ya egemen olabilmeleri için aldıkları ilk kalelerden olmuştur. ${ }^{31}$

Selçuklular Bizans hâkimiyetindeki Konya ve çevresi ile Gevale Kalesi’ni Romanûs Makri ${ }^{32}$ adlı Bizans valisinden ele geçirmiştir. ${ }^{33}$ Konya bu fetihten sonra Anadolu Selçuklu Devleti'nin başkenti ve merkezi olmuştur. ${ }^{34}$

Gevale Kalesi ve çevresi tarih boyunca önemli mücadelelerin yaşandığı bir alandır. Haçlı seferleri ve Sultan I. Mesut ile Bizans İmparatoru Manuel Kommen arasındaki savaşta Selçuklu sultanlarının buraya sığınması, elçileri kabul etmeleri ve bazı tutsakları hapsetmeleri, kalenin korunaklı ve donanımlı olduğu kadar aynı zamanda prestijli bir mekân olduğunu da göstermektedir. ${ }^{35}$

Anadolu'yu baştanbaşa etkileyen Haçlı seferleri Konya'yı da etkilemiş, şehir haçlılar tarafından yağmalanmıştır. III. Haçlı seferlerinde Konya'nın haçlılar tarafından kuşatılması üzerine III. K1lıçarslan Gevale Kalesine sığınmıştır. ${ }^{36}$

Sultan I. Gıyaseddin Keyhüsrev kardeşini ve oğlu III. Kılıçarslan'ı bir müddet kalede tutmuştur. Kılıçarslan burada öldürülmüşs ${ }^{37}$, sultan Alâeddin Keykubat elçileri kalede kabul etmiştir ${ }^{38}$. Tutsakların burada tutulması ve elçi kabullerinden dolayı Selçuklular döneminde Gevale Kalesi'nin donanımlı ve korunaklı bir yapı olduğunu da söylemek mümkündür.

Saadeddin Köpek Selçuklu döneminin önemli ilim adamı ve komutanı olan Kemaleddin Kamyar gibi devrin ileri gelenlerini Gevale Kalesi zindanında şehit etmiştir. ${ }^{39}$

IV. K1lı̧̧arslan döneminde Muineddin Pervane ile Karaman Beyi'nin Gevale Kalesi önündeki mücadelesinde Karamanoğulları tarafı kaybetmiştir. ${ }^{40} \mathrm{Bu}$ galibiyetin sonucunda Rükneddin Kılıçarslan, Karamanoğulları beylerini kalede hapsetmiştir. ${ }^{41}$

${ }^{30}$ Tuncer Baykara, Türkiye Selçukluları Devrinde Konya (Konya: Kültür ve Turizm Bakanlığı Yayınları, 1985), 32.

${ }^{31}$ Mehmet Önder, Gez Dünyayı Gör Konya'yı (Konya: Konya Büyükşehir Belediyesi Yayınları 1999), 71.

${ }^{32}$ Uzunçarş111, Osmanl Tarihi, 1; Erdoğan Merçil, Müslüman- Türk Devletleri Tarihi (Ankara: Türk Tarih Kurumu, 1993),105; Konyal1, Abideleri Ve Kitabeleri ile Konya Tarihi, 40.

${ }^{33}$ Osman Turan, Selçuklular Zamanında Türkiye (İstanbul: Boğaziçi Yayınları,1998), 54; Muzaffer Erdoğan, “Osmanlı Devrinde Anadolu Camilerinde Restorasyon Faaliyetleri”, Vakiflar Dergisi 7 (1968), 159; Yinanç, "Anadolu'nun Fethi", 6/201.

${ }^{34}$ Sevim -Merçil, Selçuklu Devletleri Tarihi Siyaset, Teşkilât ve Kültür, 90; Önder, Gez Dünyayı Gör Konya'yl, 18; Yusuf Küçükdağ. - Caner Arabacı, Selçuklular ve Konya (Konya: Mikro Yayınları, 1999), 71-229; İ. Hakk1 Konyalı, Nasreddin Hoca'nın Şehri Akşehir Tarihî- Turistik Kllavuz (İstanbul: Numune Matbaası Yayınları, 1945), 31; A. Sefa Odabaşı, 20. Yüzyıl Başlarında Konya’nın Görünümü (Konya: Konya Valiliği İl Kültür Müdürlüğü Yayınları, 1998), 11; Atçeken, Konya'daki Selçuklu Yapılarının Osmanlı Devrinde Bakımı ve Kullanılması, 10; Zeki Atçeken, “Karamanoğulları'na Kadar Konya'nın Kısa Tarihi”, Yeni İpek Yolu Dergisi, (Hz. Mevlânâ'nın 728. Vuslat Yıldönümü Anisına Özel Sayı) (Aralık 2001), 67; Yusuf Ayönü, "SelçukluBizans İlişkileri”, Türkler, ed. Hasan Celal Güzel vd. (Ankara: Yeni Türkiye Yayınları, 2002), 6/ 600.

${ }^{35}$ Konyal1, Abideleri ve Kitabeleri ile Konya Tarihi, 48-49.

${ }^{36}$ Konyal1, Abideleri ve Kitabeleri ile Konya Tarihi, 52-53.

${ }^{37}$ İbn Bibi, El-Evâmirü'l-Alâ'iyefi'l-Umûri'l-Alâ'iye (Selçuknâme), haz. Mürsel Öztürk (Ankara: Türk Tarih Kurumu, 1996), 1/ 108; Turan, Selçuklular Zamaninda Türkiye, 274; Önder, Gez Dünyayı Gör Konya 'yl, 21; İ.H. Konyal, Abideleri ve Kitabeleri ile Konya Tarihi, 583; Besim Darkot, "Konya", Türkiye Diyanet Vakfi İslâm Ansiklopedisi, (İstanbul: Diyanet Vakfi Yayınları, 1977), 6/845.

${ }^{38}$ Ahmet Eflakî, Ariflerin Menkıbeleri, çev. Tahsin Yazıcı (İstanbul: Milli Eğitim Bakanlığı Yayınları, 1995), $1 /$ 208; Turan, Selçuklular Zamanında Türkiye, 330-331.

${ }^{39}$ İbn Bibi, El-Evâmirü'l-Alâ'iyefi'l-Umûri'l-Alâ'iye (Selçuknâme), haz. Mürsel Öztürk, 2/33; Turan, Selçuklular Zamanında Türkiye, 411; M. Ferit Uğur, "Takkeli Dağ”, Konya Halkevi Dergisi 5 (2 Kanun 1937), 302.

${ }^{40}$ Şikarî, Karamannâme (Zamanın Kahramanı Karamanîler'in Tarihi), haz. Metin Sözen-Necdet Sakaoğlu (İstanbul: Karaman Valiliği Yayınları 2005), 24; İ. Hakkı Konyalı, Âbideleri ve Kitâbeleri İle Karaman Tarihi 
1292 yılında Eşrefoğlu Süleyman Bey Gevale Kalesi’ni kısa süreliğine de olsa elinde tutmuştur. $^{42}$

Anadolu Selçuklu devletinin zayıflaması ile Karamanoğlu Musa Bey 1329'da kaleyi ele geçirerek 150 yıl kadar hâkimiyet sağlamıştır. Karaman seferine çıkan Fatih Sultan Mehmet 14661467 yıllarında kaleyi taştan top gülleri ile yıktırarak Osmanlı hâkimiyetine dâhil etmiştir. ${ }^{43}$

Selçuklu ve Karamanoğulları dönemlerinde kritik zamanlarda, devlet adamları sıkışınca devlet hazinesi ile ordunun bir kısmı Gevale Kalesi'ne nakledilmiş, dolayısıyla "daru'l-mülk", yani hükümdarın ikamet ettiği yer olarak da isimlendirilmiştir. Kaynaklarda kalenin çevresinde zengin ormanların olduğu, bostanların yetiştiği dönemin sultanlarının kalenin çevresini av ve eğlence için kullandıklarından da bahsedilir. ${ }^{44}$ Ayrıca Mevlânâ ve Arif Çelebi'nin zaman zaman kaleye çıkarak buradaki papazlarla yapmış olduğu sohbetlerine de yer verilir. ${ }^{45}$

Kale yüksek olduğu için hilalin en net görüldügü mevki idi. Osmanlı döneminde Ramazan ayının başlangıcı ve bayram gününün tespiti, yani rü’yet-i hilâl için de kullanılmıştır. ${ }^{46}$

Kale Demir çağı, Roma, Bizans, Selçuklu, Beylikler ve Osmanlı devirlerinde kullanılmış olup, bu dönemlerden izler taşımaktadır. Kaynaklar kale hakkında birçok bilgi vermektedir. ${ }^{47}$ Taranan kaynaklar, yapılan yüzey araştırmaları ve kazılar Gevale Kalesi hakkında bilinmeyen birçok hususu aydınlığa kavuşturmuştur.

\section{Seramik Kap Türleri ve Formları}

Gevale Kalesi kazılarında seramiklerin çok azı tam ya da tama yakın, büyük bir kısmı da parçalar halinde ortaya çıkartılmış ve daha sonra üzerinde uzun süre çalışlarak tümlenmeye çalışılmıştır. Bu çalışmada sırlı seramiklerden form veren örnekler incelenmiştir.

Seramik formlarının isimlendirilmesinde daha önce yapılmış yayınlarda birliktelik bulunmamaktadır. Söz konusu yayınlardan da yararlanılmış, benzer özelliklere sahip örnekler üzerinden değerlendirme yapılarak gruplandırmaya gidilmiştir. ${ }^{48}$

Ermenek ve Mut Âbideleri (İstanbul: Baha Matbas1, 1967), 47; Turan, Selçuklular Zamanında Türkiye, 520; Merçil, Müslüman- Türk Devletleri Tarihi, 302; Tahsin Ünal, Karamanoğulları Tarihi (Konya: Karaman Esnaf ve Kefalet Kooperatifi, 1986), 53; M. Önder, Mevlâna Şehri Konya, (Ankara: Konya Turizm Derneği Yayınları, 1971), 24; İsmail Hakkı Uzunçarşı1l, Anadolu Beylikleri ve Akkoyunlular, Karakoyunlu Devletleri Ankara: Türk Tarih Kurumu, 1988, 2-3; Uğur, "Takkeli Dağ", Konya Halkevi Dergisi, 303; M. Zeki Oral, “ Fatih Sultan Mehmet'in Gevale Kalesi İle Karaman İllerini Fethi ve Hamîdî’nin Terci-i Bendi”, Vakfflar Dergisi (1958), 4/85; Zerrin Günal Öden, "Karamanoğulları Beyliğì, Türkler, ed. Hasan Celal Güzel vd. (Ankara: Yeni Türkiye Yayınları, 2002), 6/756.

${ }^{41}$ İbn Bibi, El-Evâmirü'l-Alâ'iyefi'l-Umûri'l-Alâ'iye (Selçuknâme), haz. Mürsel Öztürk, 2/ 202-203; Şikarî, Karamannâme (Zamanın Kahramanı Karamanîler'in Tarihi), haz. Metin Sözen - Necdet Sakaoğlu, 20-23; Turan, Selçuklular Zamanında Türkiye, 521; Konyal, Âbideleri ve Kitâbeleri ile Karaman Tarihi Ermenek ve Mut Âbideleri, 11; Uzunçarșıll, Osmanlı Tarihi, 43-45; Ünal, Karamanoğulları Tarihi, 55-56; Önder, Mevlâna Şehri Konya, 27-28; H. F. Turgal, "Konya Tarihinin Mühim Bir Safhası Muhtasar İbn Bibiye Göre Cimri Vak'ası", Konya Halkevi Dergisi 3 (2 Teşri 1936), 152; Tahsin Ünal, "Karaman Oğlu Mehmet Bey”, Anit 10 (Kasım 1949), 3.

${ }^{42}$ Turan, Selçuklular Zamanında Türkiye, 606; Merçil, Müslüman- Türk Devletleri Tarihi, 163, 165, 295; Şimşirgil, "Eşrefoğulları Beyliğì", 6/ 772.

${ }^{43}$ Şen, "Konya Gevale Kalesi Kazılarında Bulunan Taş Gülleler", 208.

${ }^{44}$ Konyall, Abideleri Ve Kitabeleri ile Konya Tarihi, 175,169.

${ }^{45}$ Ahmet Eflakî, Ariflerin Menkıbeleri, çev. Tahsin Yazıcı, 1/ 498-500.

${ }^{46}$ Barış Sarıöse, Osmanlı Döneminde Sille (Konya: Çizgi Kitabevi Yayınları, 2008), 24,211.

${ }^{47}$ Özdeniz, Gevale Kalesi Kazılarında Bulunan Ortaçağ Seramikleri, 6-14.

${ }^{48}$ Muharrem Çeken, "Kubad Abad Sarayı Selçuklu Seramikleri”, Anadolu Türk Devri Çini ve Seramik Sanatı, ed. Gönül Öney - Zehra Çobanlı (İstanbul: Kültür ve Turizm Bakanlığı Yayınları. 2007), 111-119. 
Kaplar farklı form ve ölçülerde karşımıza çıkmaktadır. Çeşitli tür, form ve ölçülere ait örnekler genel olarak; kâseler, tabaklar, testiler ve çömleklerdir. Belirli bir forma sahip olmasına rağmen türü belirlenemeyen örnekler ise kaideler ve gövdeler olarak adlandırılmış, bu seramik parçaları benzer özelliklere sahip diğer kaplar göz önü alınarak türleri hakkında tahminler yürütülmüştür.

Kâse ve tabakların özelliklerine bakılarak bunların sıvı ve katı yiyeceklerin konulduğu günlük kullanım için yapılmış kaplar olduğu söylenebilir. ${ }^{49}$ Iş̧̧ilik ve süsleme açısından daha kaliteli olan kaplar ise günlük kullanım için değil özel günlerde, özel mekânlarda ve özel kişiler tarafindan kullanıldığı bilinmektedir.

Derin kaplardan çömleklerin depolama amaçlı olarak kullanılmış olduğu söylenebilir. Testilere ise sıvı maddeler katılarak faydalanılmıştır.

Farklı forma sahip örnekleri içeren toplam altmış iki örnek kendi içinde ayrı ayrı başlıklar altında ele alınarak tanıtılmaya çalışılmıştır.

\section{Kâseler}

Kâseler derin kaplar olup, ağız ve gövde formlarına göre farklılıklar içermektedir. Yükseklikleri ve ağız çapları tam olarak belirlenen örnekler ile tahmini yükseklikleri ve ağız çapları öngörülen seramik kaplar; gövde ve ağız profillerine göre çeşitli alt gruplarda incelenmiştir. ${ }^{50}$ Bunlar; (a) küresel gövdeli, dışa çekik konik kenar ağızlı, halka kaideli, (b) küresel gövdeli, halka kaideli, (c) konik gövdeli, iç bükey profilli, ağzı dik kenarlı, halka kaideli ve (d) konik gövdeli, dışa genişleyen ağızlı kâseler olmak üzere dört grup şeklinde karşımıza çıkmaktadır.

Kâseler içinde yüksekliği en fazla olan sır altı teknikli $(12 \mathrm{~cm})$ kaptır (Fot. 1). En geniş ağız çapına sahip olan $(34 \mathrm{~cm}$ ) sigrafitto teknikli örnektir (Fot. 2).

Kâselerden yükseklik ve ağız çapı en küçük olan örnekse $6,5 \mathrm{~cm}$ yüksekliğe ve $15 \mathrm{~cm}$ ağız çapına sahip sır altı tekniğiyle imal edilmiş kaptır (Fot. 3).

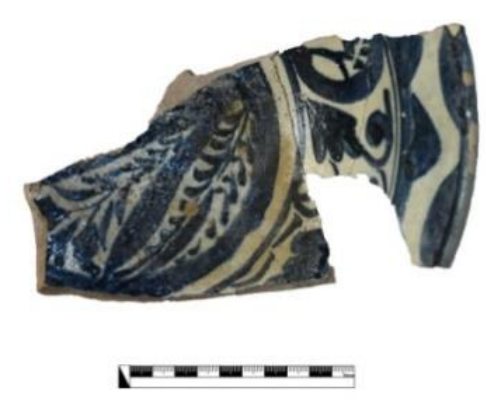

Fotoğraf 1

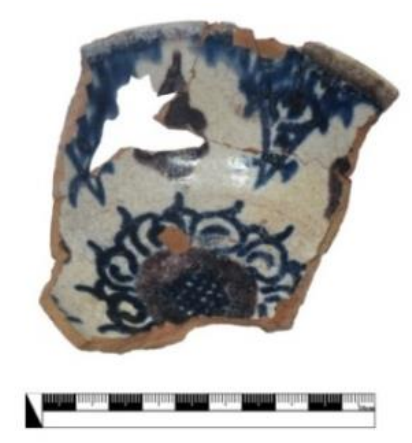

Fotoğraf 2

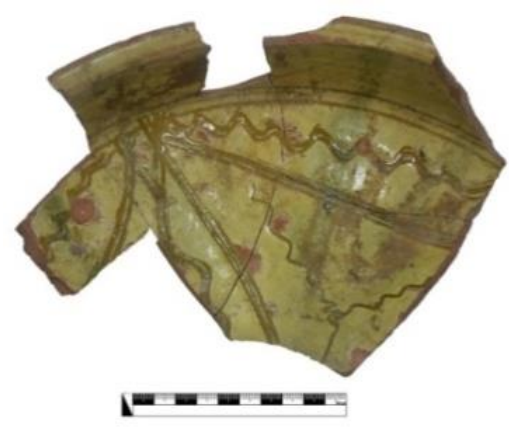

Fotoğraf 3

Küresel gövdeli, dışa çekik konik kenar ağızlı ve halka kaideli kâselerin ağız çapları $13 \mathrm{~cm}$ ile $30 \mathrm{~cm}$ arasında değişmektedir (Tablo 1). Tam form veren kâselerden elde edilen yükseklik ise $10,5 \mathrm{~cm}$ ile $12 \mathrm{~cm}$ arasında değişmektedir. Kâselerde gövdeden ağza doğru hamur kalınlığı incelmektedir. Ağız

\footnotetext{
${ }^{49}$ Muradiye Öztaşkın, "Proposal for Terminology of Byzantine Pottery Forms", XI. Alecm3 Uluslararası Orta Çă ve Modern Akdeniz Dünyası Seramik Kongresi Bildirileri 1(Ekim 2015), 331.

50 Turgay Polat, "Milet İşi Seramiklerde Form Tipolojisi Üzerine Bir Deneme”, Sanat Tarihi Dergisi 25 (Ekim 2016), 217.
} 
formundaki profiller farklılık gösterse de temelde konik ağız yapısına sahiptirler. Bu kâselerde tek renk sir, sir alt1 ve sigrafitto tekniği görülmektedir.
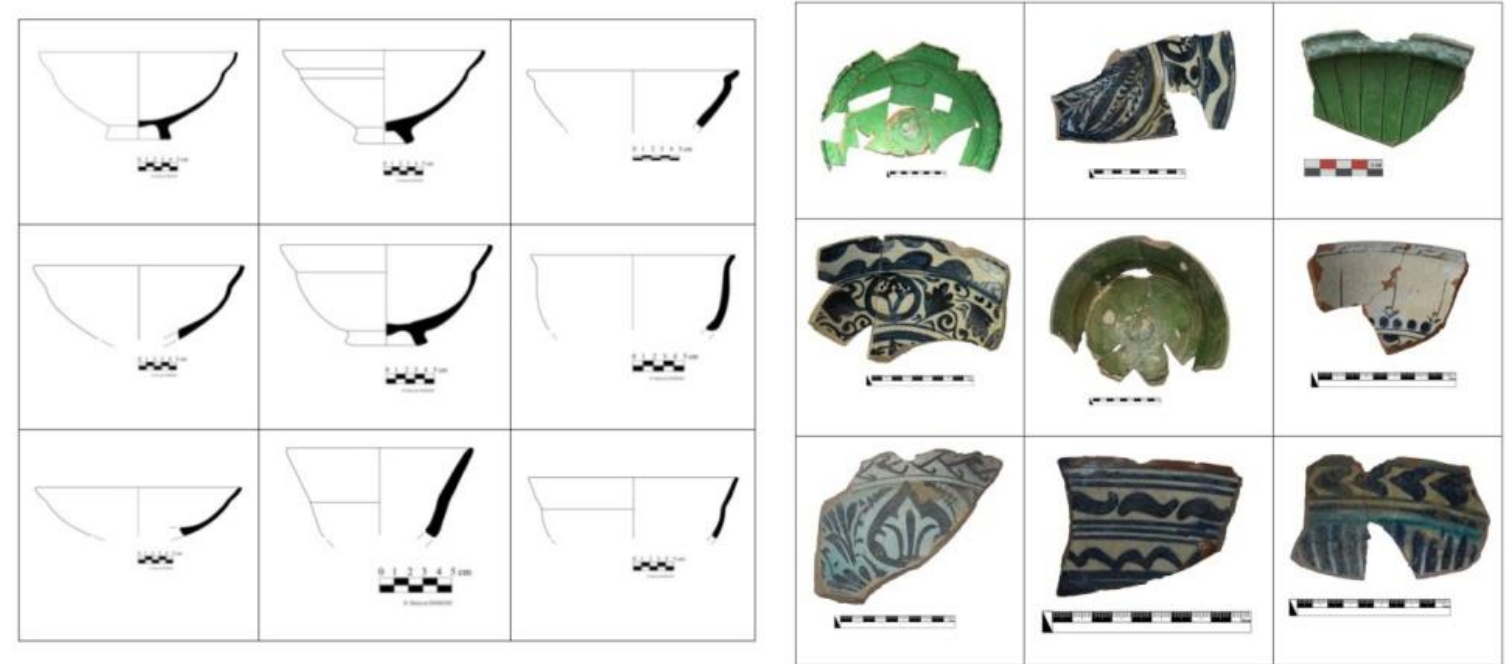

Tablo 1: Küresel gövdeli, dışa çekik konik kenar ağızlı, halka kaideli kâseler

Küresel gövdeli, halka kaideli kâseler; sır altı, sigrafitto ve tek renk sır tekniği ile bezenmiş seramiklerde görülmektedir (Tablo 2). Bu gruptaki seramiklerin ağız çap1 $15 \mathrm{~cm}$ ile $28 \mathrm{~cm}$ arasında değişmektedir. Kâse yükseklikleri ise $8,2 \mathrm{~cm}$ ile $9,5 \mathrm{~cm}$ arasında muhteliftir. Bu örneklerde gövde ve ağızda hareketlilik daha azdır.
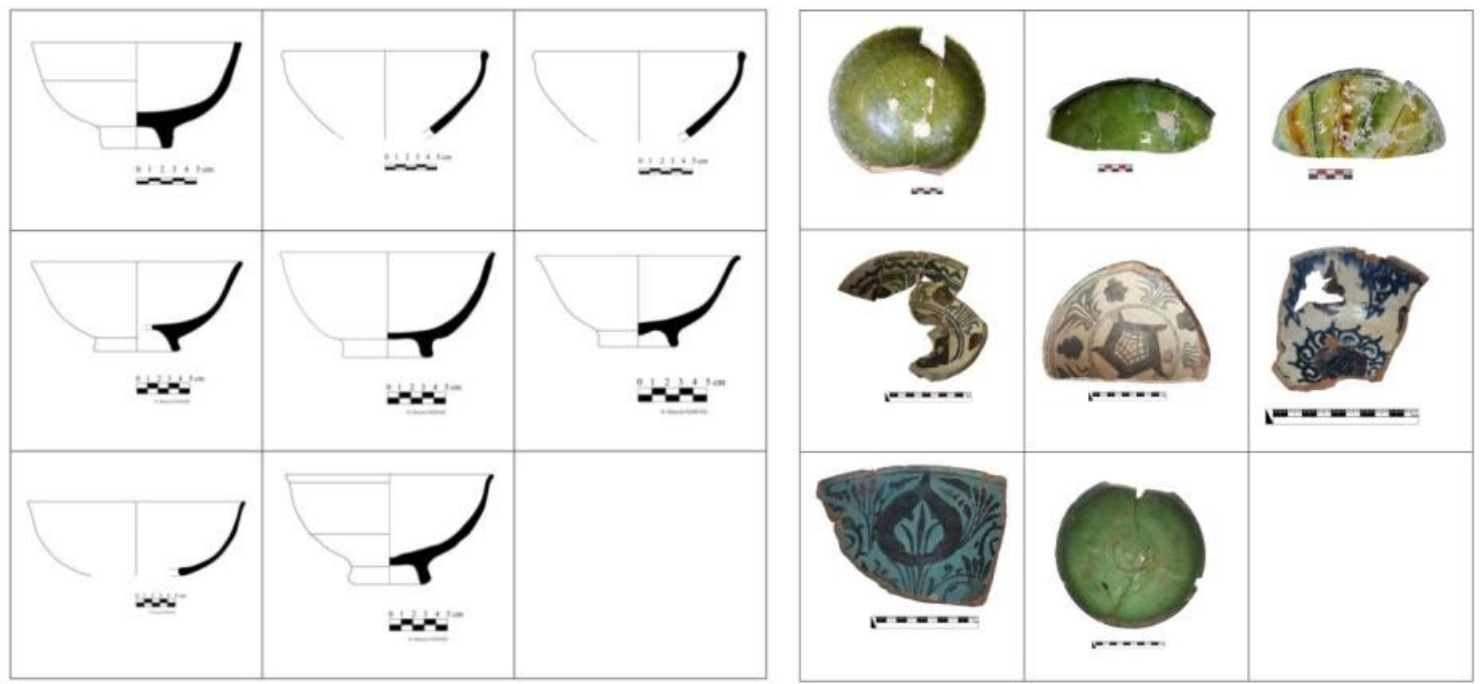

Tablo 2: Küresel gövdeli, halka kaideli kâseler

Konik gövdeli, iç bükey profilli, dik ağız kenarlı, halka kaideli kâselerin tamamı tek renk sırlı olup, bezeme içermeyen örneklerden oluşmaktadır (Tablo 3). Ağız çapları $20 \mathrm{~cm}$ ile $34 \mathrm{~cm}$ arasında değişiklik göstermektedir. Yükseklikleri ise $8,2 \mathrm{~cm}$ ile 11,8 cm arasında farklılık içerir. Bu grupta ağız formlarının neredeyse tamamında farklılık görülse de kapların ortaya koyduğu formlar konik gövdeli ve dik ağızlıdır. 

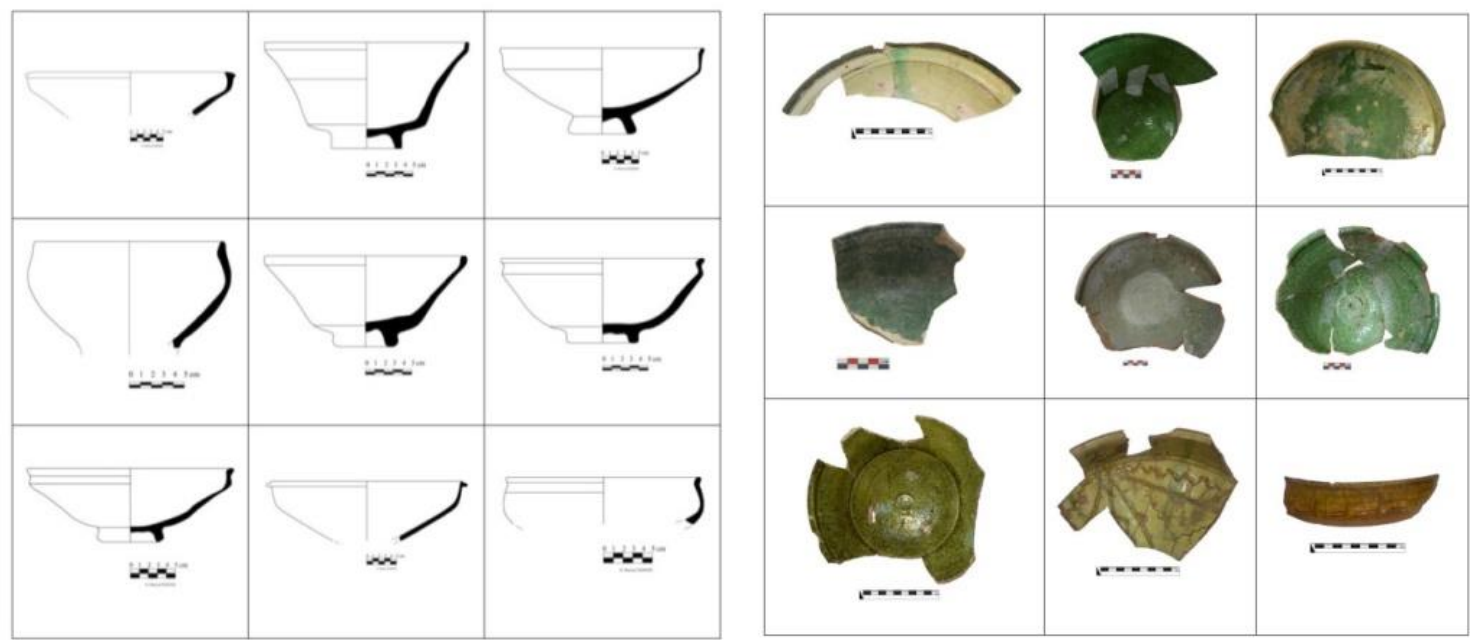

Tablo 3: Konik gövdeli, iç bükey profilli, dik ağız kenarll, halka kaideli kâseler

Konik gövdeli, halka kaideli kâse grubu içinde üç örnek ele alınmıştır (Tablo 4). Bunlardan ikisinin ağız ve gövde kısmı mevcut olup, kaide bölümleri bulunmamaktadır. Tam form veren tek örnek vardır. Bu örneklerden ikisi sır altı, biri de sıgraffito tekniği ile bezenmiştir.

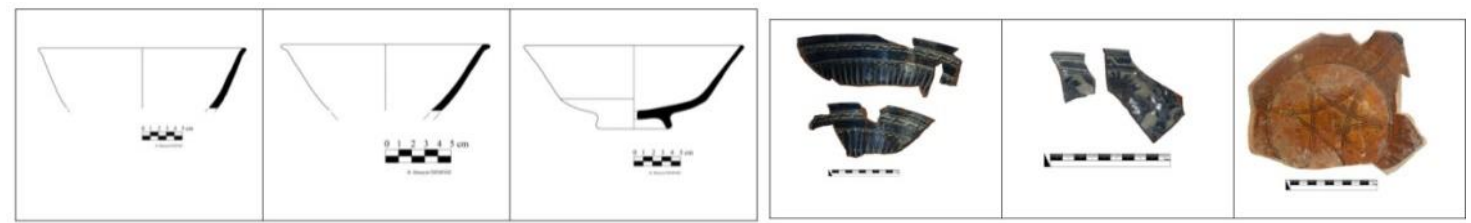

Tablo 4: Konik gövdeli, halka kaideli kâseler

Kâse grubu içerisinde küresel gövdeli, içe dönük ağızlı, halka kaideli tek örnek mevcuttur (Çizim:1). Çoklu parçadan oluşan seramik kabın ağız formu belli iken gövde ve kaide formu bilinmemekte olup, $26 \mathrm{~cm}$ ağız çapına sahiptir. Kâsenin gövdesi sigrafitto tekniğinde yatay çizgilerle bezenmiştir.

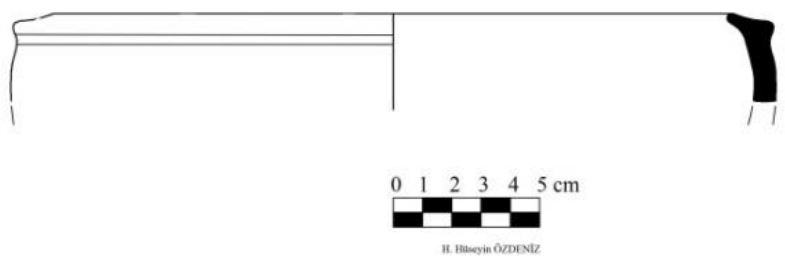

Çizim 1

\section{Tabaklar}

Genellikle tabakların yükseklikleri kısa ve ağız çapları geniştir. Ağız formları farklı olsa da hepsinin gövdeleri yayvandır. Büyük bir kısmının kaidesi bulunmazken kaidesi ile birlikte tam form veren örnekler de vardır. Bu örneklerden alınan ölçülere göre yükseklikleri $5 \mathrm{~cm}$ ile $6.7 \mathrm{~cm}$ arasında değişmektedir. Yine form veren tabaklardan alınan ölçülerde ise ağız çapları $23 \mathrm{~cm}$ ile $26 \mathrm{~cm}$ arasında farklılık göstermektedir. Kaidesi olmayan, gövde ve ağız kısmının bir bölümü ele geçen tabakların tahmini ağız çapları $23 \mathrm{~cm}$ ile $36 \mathrm{~cm}$ arasında değişmektedir. 
Tabaklar içerisinde en yaygın olan tip; yayvan gövdeli, dışa çekik profilli, geniş ağızlı, halka kaideli kaplardır (Tablo 5). Bunların ağız açıları muhteliftir. ${ }^{51}$ Sır altı tekniği ile yapılmış bitkisel ve geometrik bezemeli örneklerin çoğunluğu bu grupta yer almaktadır.
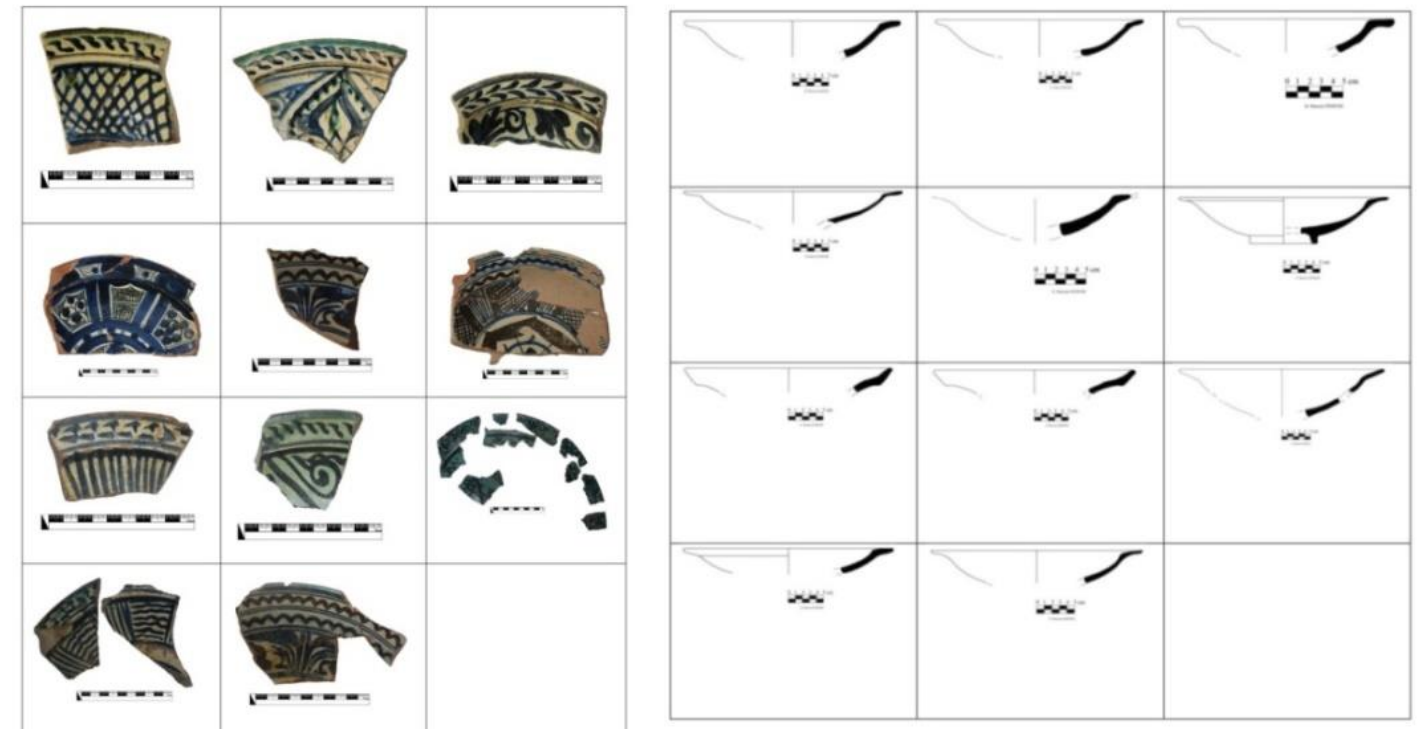

Tablo 5: Yayvan gövdeli, dışa çekik profilli, geniş ă̆ız kenarl, halka kaideli tabaklar

Dışa genişleyen gövdeli tabaklar en geniş ağza sahip olup, büyük çoğunluğu tek renk sırlıdır ${ }^{52}$ (Tablo 6). Sadece bir örneği slip tekniği ile tezyin edilmiş, kaidesi bulunmayan $30 \mathrm{~cm}$ çapa sahip olan tabaktır. ${ }^{53}$
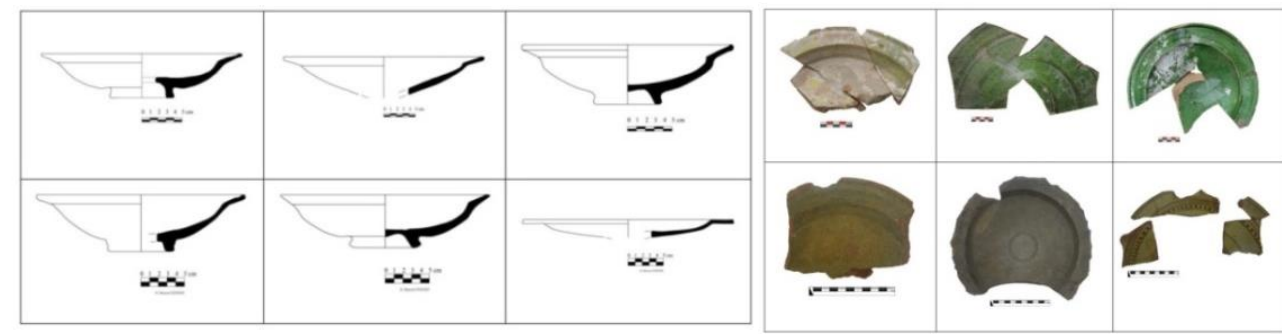

Tablo 6: Dışa genişleyen gövdeli, geniş ağızlı tabaklar

Tabaklar içerisindeki ikinci grup ise; halka kaideli, yayvan gövdeli, dışa çekik iç bükey profile sahip, geniş ağız kenarlı tabaklardır (Tablo 7). Tamamı tek renk sırlı olan tabakların ağız çapları $23 \mathrm{~cm}$ ile $25 \mathrm{~cm}$ arasında değişmektedir. Biri dışında diğer örneklerin kaideleri bulunmamaktadır.
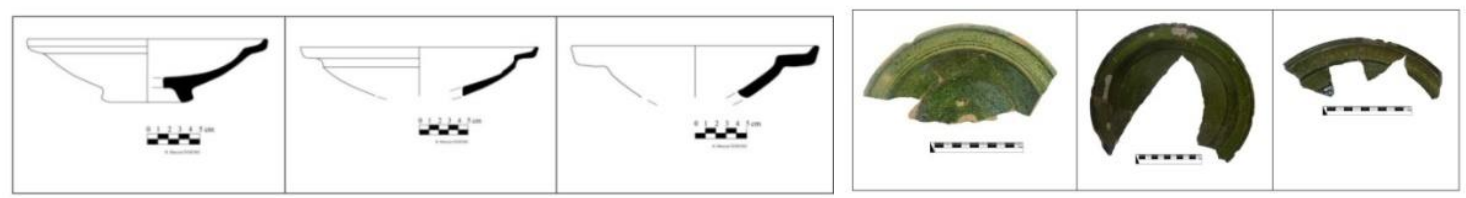

Tablo 7: Yayvan gövdeli, dışa çekik iç bükey profilli tabaklar

\footnotetext{
${ }^{51}$ Benzer örnekler Milet ve Amorion da ortaya çıkarılmış seramiklerde görülmektedir. Bk. Beate BöhlendorfAslan, "Die Beziehungen Zwischen Byzantinischer und Emiratszeitlicher Keramik", 151,155.

52 Benzer örnek için bk. Melih Yardımcı, Şavşat Kalesi Kazısı Sirlı ve Sirsı Seramik Buluntularının Değerlendirilmesi (Van: Yüzüncü yıl Üniversitesi, Sosyal Bilimler Enstitüsü, Yüksek Lisan Tezi, 2015), 102.

${ }^{53}$ Benzer örnek için bk. Sevinç Gök Gürhan, Akşsehir Taş Medrese Müzesindeki Türk Dönemi Seramikleri (İzmir: Ege Üniversitesi, Sosyal Bilimler Enstitüsü, Doktora Tezi, 2007), 27.
} 
Halka kaideli, dışa doğru genişleyen yayvan gövdeli, düz bir şekilde biten ağız kısmına sahip tabaklar bu grubun en sade kap formudur (Tablo 8). Bunlardan ikisi sır altı, biri minâî tekniğiyle tezyin edilmiştir.
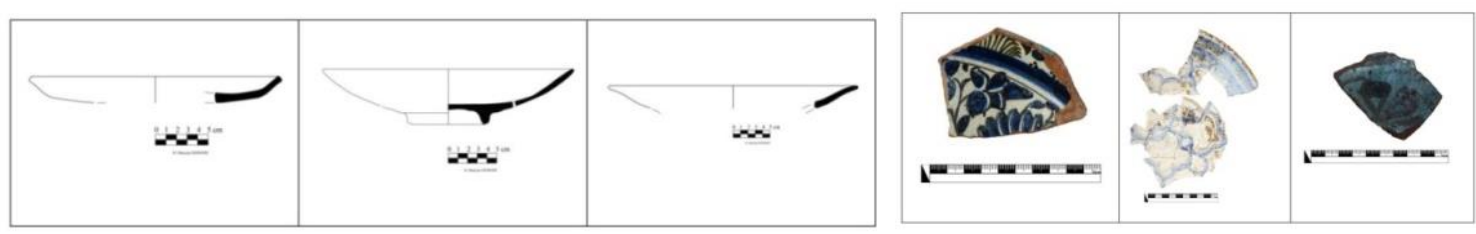

Tablo 8: Yayvan gövdeli, halka kaideli tabaklar

Tabaklar içerisindeki sadece bir örneğin gövdesi yatay bir şekilde devam ederek dik bir ağızla son bulmaktadır (Çizim 2). $31 \mathrm{~cm}$ ağız çapına sahip kabın kaide bölümü yoktur.

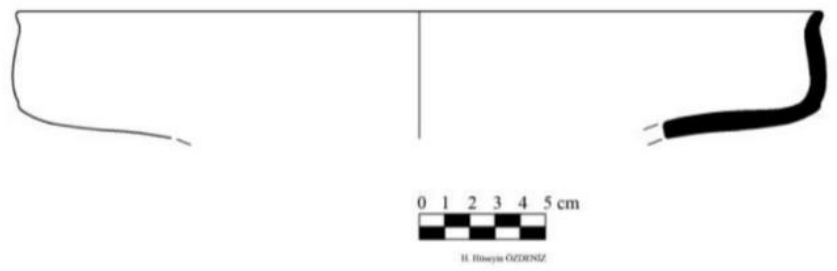

Çizim 2: Yayvan gövdeli, dik ă̆ızlı tabak

\section{Testiler}

Gevale Kalesi kazılarında dört adet sırlı testi ele geçmiştir. Testilerin tamamı kulplu olup, farklı gövde, boyun ve ağız formlarına sahiptir. Üç testi tek renk sır, bir örnek ise slip tekniği ile bezenmiştir. Tek renk sırlı olan testilerde bezeme görülmemektedir.

Testilerin ikisinin uzun boyunlu olduğu görülmektedir. Bunlardan biri ince uzun (Çizim 7), diğeri ise ağza doğru genişleyen boyna sahiptir (Çizim 8).

Diğer ikisinin de ağız ve gövde arası daralarak boyun kısımları kısa tutulmuştur. Kısa boyna sahip iki testi de tek renk sırla kaplıdır (Çizim 9-10).

Testilerin gövdelerini incelendiğinde; ince uzun gövde ile geniş karınlı gövdeye sahip olmak üzere iki farklı form görülmektedir. Geniş karınlı gövdeye sahip üç örnekten birinin gövdesi nervürlü (Çizim 7), ikincisi geniş karınlı, slip tekniği ile bezeli (Çizim 8), Üçü ise kısa boyunlu olup, tek renk sırlıdır (Çizim 10). Dördüncü testi ise dar karınlı, kısa boyunlu ve tek renk sırlıdır (Çizim 9).

Testi örneklerinin tamamında kulp bulunmaktadır. Elde şekillendirilmiş ve sonradan eklenmiştir. İki örnekte gövdeden başlayan kulplar ağız kenarında sonlanmaktadır. Diğer testide ise gövdeden başlayan kulp ince uzun boynun ortasına bağlanmaktadır. Geniş karınlı ve nervürlü örnekte ise gövdeden başlayan kulp testinin boyun seviyesinden itibaren kırık olduğundan kulpun nereye bağlandığı bilinmemektedir.

Testilerin ağız formları incelendiğinde; üç testinin de ağız formlarının ayrı olduğu görülmektedir. Bir testinin ağız formu ise boyun seviyesinden itibaren kırık olması nedeniyle bilinememektedir (Çizim 3). Slip tekniği ile bezeli testinin ince uzun boynu hafif genişleyerek dışa çekik halka ağızla bitmektedir (Çizim 4). Tek renk kobalt mavisi sırlı, geniş karınlı olmayan testinin ağzı ise yonca formunda bitmektedir (Çizim 5). Tek renk mat yeşil sırlı olan testinin ağzı ise geniş 
tutulmuş ve daha sonra seramik hamuru yaş iken iki yönden bastırılarak iki kenara birleştirilmiştir. $\mathrm{Bu}$ şekilde testinin ağzında küçük bir emzik oluşturulmuştur (Çizim 6).

Yukarıda gövde, kulp ve ağız formu tanımlanan testilerin kaide kısımları kırık olmasına rağmen düz kaideli olması gerektiği düşünülmektedir.

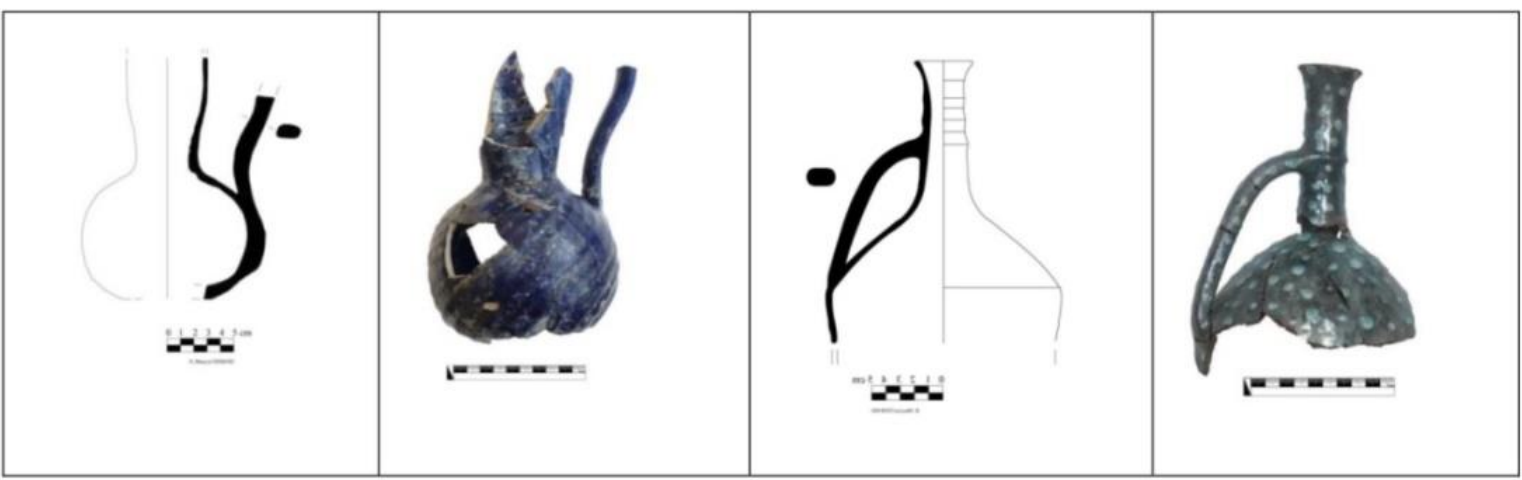

Çizim 3

Çizim 4

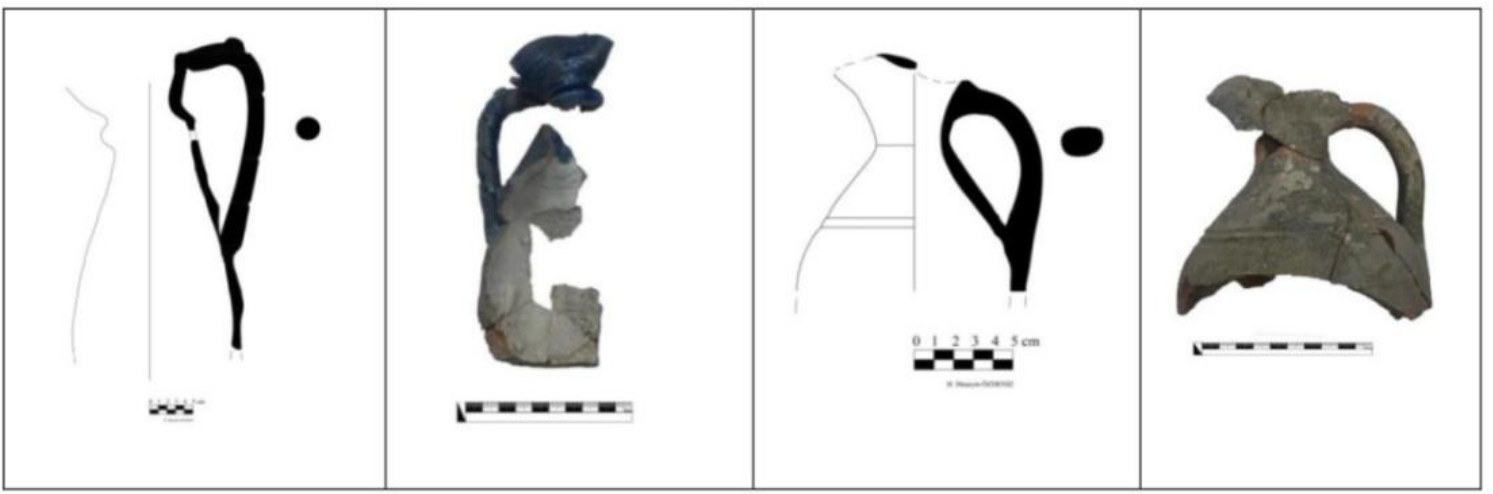

Çizim 5

Çizim 6

\section{Çömlekler}

Gövde ve ağız formu bilinen seramik kapların dışında yine derin kap olduğu anlaşılan, farklı tür ve forma sahip kaplar çömlekler olarak ele alınmıştır. Bu kapların ortak yönleri derin kap özelliklerine sahip olmalarıdır. Her üç çömlek de kısa boyunlu ve geniş karınlıdır. Bunlardan ikisi kırık olduğundan kaide kısmı anlaş1lamamakta, birinde ise kabın bütün formu okunabilmektedir (Fot. 6, Çizim 9). Kulp sadece bir örnekte vardır (Fot. 5, Çizim 8). İnsan çehresinin işlendiği örnek sigrafitto (Fot. 4, Çizim 7), diğer ikisi ise tek renk sır (Fot. 5-6, Çizim 8-9) tekniğiyle bezenmiştir.

Kısa dik ağızlı, boyundan gövdeye doğru genişleyen çömleğin kaide kısmı kırıktır ${ }^{54}$ (Fot. 4, Çizim 7). Yüksekliği 12,3 cm olan kabın ağız çapı 12,5 cm'dir. Çömleğin gövdesinde yatay geniş bir bordürde daire içerisine alınmış yatay düz kaşlı, badem gözlü, küçük burun ve ağızlı üç adet insan yüzü tasvir edilmiştir. ${ }^{55}$ Figürlerin arası da ters palmet ve dört kollu madalyonlarla tezyin edilmiştir.

\footnotetext{
${ }^{54}$ Çeken, "Kubad Abad Sarayı Kazısı Selçuklu Seramikleri”, 115.

55 Benzer örnekler için bk. Mustafa Ağatekin, Selçuklu Dönemi Seramik Yüzeylerinde Insan Betimlemeleri (Eskişehir: Anadolu Üniversitesi, Sosyal Bilimler Enstitüsü, Sanatta Yeterlilik Tezi, 2003), 73.
} 


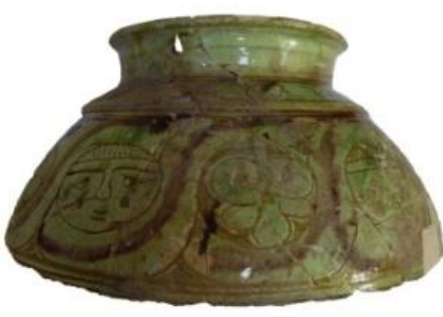

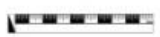

Fotoğraf 4

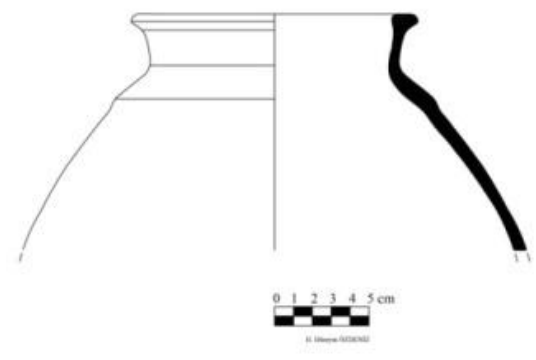

Çizim 7

Bu grupta ele aldığımız ikinci örnek ise $12 \mathrm{~cm}$ yüksekliğe, $24 \mathrm{~cm}$ ağız çapına sahip tek renk sırlı kaptır. Dik ağızlı, ağızdan gövdeye doğru genişleyen karnında kulp bulunmaktadır (Fot. 5, Çizim 8).

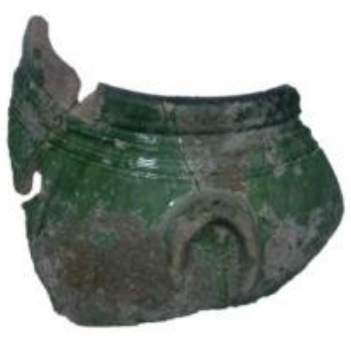

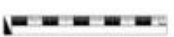

Fotoğraf 5
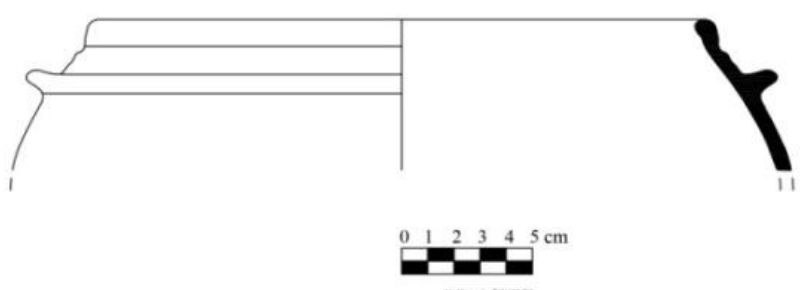

Çizim 8

Son çömlek ise $13 \mathrm{~cm}$ yüksekliğe ve $6 \mathrm{~cm}$ ağız çapına sahiptir. Düz boyunlu, geniş karınlı ve düz kaideli olup, tek renk sırla kaplıdır (Fot. 6, Çizim 9).

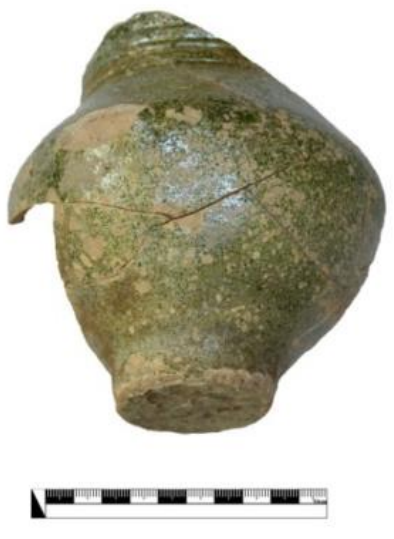

Fotoğraf 6

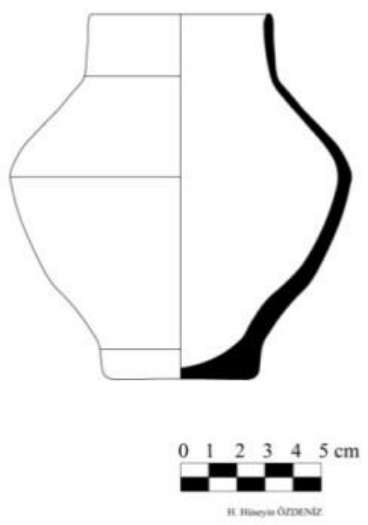

Çizim 9

Sigrafitto tekniği ile yapılmış geometrik bezemeli kapak $6 \mathrm{~cm}$ yükseklikte olup, ağız çap1 13 cm'dir. Kapağın diğer ağız parçasının içine girerek kapandığı görülmektedir. Küresel bir forma sahiptir $^{56}$ (Fot. 7, Çizim 10). Yüksekliğinden ve çapından dolayı kâse veya tabağa ait değil, bu

56 Sevcan Türe, Ayasuluk Kalesi Doğu Kapısı Çevresindeki 2000-2002 Kurtarma Kazılarında Ele Geçen Seramikler (Edirne: Trakya Üniversitesi, Sosyal Bilimler Enstitüsü, Yüksek Lisan Tezi, 2014), 242. 
parçanın ağız profilinin yüksek olmasından dolayı bir çömleğe ait kapak olduğu ihtimalini güçlendirmektedir.

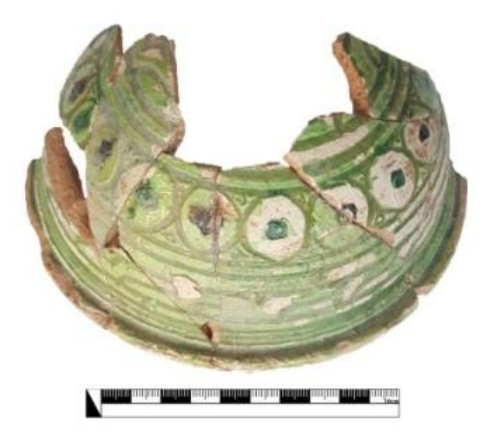

Fotoğraf 7

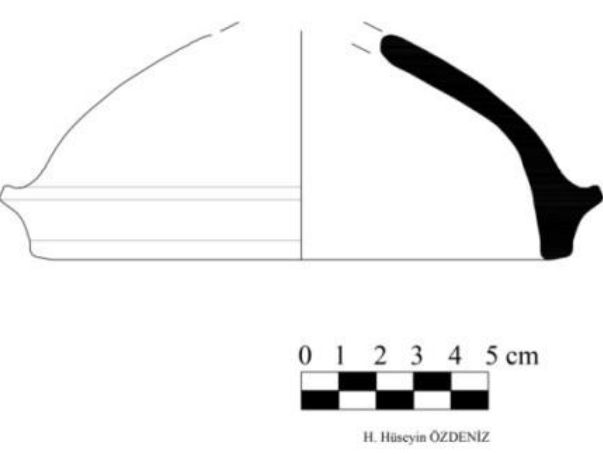

Çizim 10

Gevale Kalesi kazılarında yoğun olarak bulunan seramik parçalarından bir kısmı da kapların kaide/dip olarak adlandırılan bölümleridir. Bu grupta farklı yükseklikte, kalınlık ve çapta kaideler bulunmaktadır. Üzerinde bitkisel, geometrik, figür ve yazı karakterli karalama bezemelerin yanında bezemesiz, yalın örnekler de mevcuttur. Kaide/dip parçalarının yükseklikleri $1 \mathrm{~cm}$ ile 2,2 cm arasında değişmektedir. Çapları ise $4 \mathrm{~cm}$ ile $12 \mathrm{~cm}$ arasında farklılık arz etmektedir.

\section{DEĞERLENDIRME VE SONUÇ}

Gevale Kalesi kazılarında ortaya çıkartılan seramik buluntular kâseler, tabaklar testiler ve çömlekler başlığı altında dört ana grupta incelenmiştir. Bu tasnifte seramikler, gövde ve ağız farklılıklarından dolayı derin ve yayvan kaplar olarak da kendi içlerinde çeşitlilik göstermektedir. ${ }^{57}$

Kâseler daha çok ağız kısımlarına göre farklı1ık arz etmektedir. Dışa çekik konik kenar ağızlı, dışa çekik ağız ve iç bükey dik kenar ağızlı olmak üzere üç tip belirlenmiştir. Gövdelerine göre, konik ya da küresel gövdeli olarak da çeşitlilik göstermektedir. Kaideleri tam olan örneklerde sadece halka kaideli tip görülmektedir. ${ }^{58}$

Tabaklar ağız kısımlarına göre farklı1ık arz etmektedir. Dışa çekik profilli, geniş ağız kenarlı, dışa çekik geniş ağızlı ve dışa çekik iç bükey profilli ağız olmak üzere üç farklı tip olarak karşımıza çıkmaktadır. Gövdeler genellikle yayvan olup, halka kaidelidir.

Testiler boyunlarına göre; uzun ve kısa, gövdelerine göre ise; dar ve geniş karınlı olmak üzere farklı formlar göstermektedir. Hepsi kulplu olup, kaideleri kırık olmasına rağmen düz kaideli olduğu düşünülmektedir.

Çömleklerin üçü de kısa boyunlu ve geniş karınlı olup, düz kaidelidirler.

Seramikler krem ve beyaz astarlı, yeşil, mavi, hardal sarısı ve beyaz renkli sıra sahiptir. Seramiklerin tür ve formlarına özel süsleme kompozisyonlarının olmadığı, benzer şekillerdeki kaplarda farklı bezeme ve sır kullanımı görülebilmektedir. Kapların yüzeyleri geometrik, bitkisel desenler ve insan figürüyle bezenmiştir. Sap, yaprak ve palmet motiflerinden meydana gelen bitkisel,

57 Benzer örnekler için bk. Sema Bilici. Akdeniz Bölgesi Örneklerine Göre Ortaçă̆ Anadolu Sigrafitto Seramiklerine Materyal, Biçim, Teknik ve Stilistik Açıdan Bir Yaklaşım Tarihleme ve Bir Tipoloji Denemesi (Ankara: Ankara Üniversitesi, Sosyal Bilimler Enstitüsü, Doktora Tezi, 1992), 310-332.

58 Melih Yardımcı, Şavşat Kalesi Kazısı Sırlı ve Sırsız Seramik Buluntuların Değerlendirilmesi (Van: Yüzüncü Y1l Üniversitesi, Sosyal Bilimler Enstitüsü, Yüksek Lisan Tezi, 2015), 151-152. 
basit çizgiler, zikzaklar, zencirek ve altı köşeli yıldızlardan teşekkül eden geometrik süslemenin yanı sıra, cepheden tasvir edilmiş insan büstü ile tezyin edilmiştir.

Kaplar tek renk sır, sigrafitto, slip, sır altı ve minâî tekniği ile bezenmiştir. Ortaçağ seramik ustalarının minâî dışında diğer teknikleri yoğun olarak uyguladıkları dikkati çekmektedir. Minâî tekniği ise Büyük Selçuklu döneminde çok yaygın olmasına rağmen Anadolu'da yalnız II. Kılıçarslan Köşkü'nde kullanıldığı bilinmektedir. Gevale Kalesi'nde bir örnekte de olsa bu teknikte bir kabın bulunması kalenin sadece savunma yapısı değil, kaynaklarda da bahsedildiği üzere aynı zamanda sultanın av için zaman zaman bulunduğu ve elçi kabul ettiği prestijli bir mekân olduğunu da ortaya koymaktadır.

Seramikleri genel olarak 13.-15. yüzy1llara tarihlendirmek mümkün görülmektedir. Gevale seramikleri başta form, süsleme, sır ve teknik özellikleri bakımından Kubad Abâd ${ }^{59}$, Konya Zindankale (Ahmedek) ${ }^{60}$, Akşehir Taş Medrese ${ }^{61}$ Alanya Selçuklu Sarayı ${ }^{62}$, Keykubadiye Sarayı ${ }^{63}$, Hasankeyf $^{64}$, Ayasuluk Kalesi ${ }^{65}$, Eskişehir Karacahisar Kalesi ${ }^{66}$, İznik Roma Tiyatrosu ${ }^{67}$, Manisa Gülgün Hatun Hamam ${ }^{68}$ kazılarında ortaya çıkartılan örnekler ile Konya Karatay (Çini Eserler) Müzesi’ndeki seramikler ${ }^{69}$ arasında benzerlikler görülmektedir. ${ }^{70}$

Seramik buluntular, mimari kalıntılar ve diğer objelerle birlikte değerlendirildiğinde; Gevale Kalesi'nin tarihi, kültürel ve sanat özellikleri hakkında önemli bilgiler sunmuştur. Savunma mekânı olarak kullanıldığı dönemin daha iyi anlaşılmasına katkı sağlamıştır.

Ortaçağ kent merkezleri ve Gevale Kalesi gibi sınırlı yerleşime konu olmuş alanlarda yeni yapılacak arkeolojik kazılarda ortaya çıkartılacak seramik buluntuları ile müzelerde muhafaza edilen bu tür eserlerin incelenip değerlendirilmesi sonucunda Ortaçağ seramiklerinin hamur, astar, teknik, form, süsleme unsurları ile kullanımlarına yönelik nitelikleri daha iyi anlaşılmış olacaktır.

\footnotetext{
${ }^{59}$ Çeken, "Kubad Abad Sarayı Kazısı Selçuklu Seramikleri, 111-122.

60 Zehra Özcan, Konya Zindankale (Ahmedek) Kazı ve Buluntuları (Çanakkale: Çanakkale Onsekiz Mart Üniversitesi, Sosyal Bilimler Enstitüsü, Lisans Tezi, 2019), 178-184.

${ }^{61}$ Gürhan, Akşehir Taş Medrese Müzesindeki Türk Dönemi Seramikleri, 116-184.

${ }^{62}$ Sema Bilici, “Alanya-Selçuklu Sarayı Seramikleri”, Uluslararası Sanat Tarihi Sempozyumu Prof. Dr. Gönül Öney'e Armağan (İzmir: Ege Üniversitesi Yayınları, 2002), 139-154.

${ }^{63}$ Ali Baş - Şükrü Dursun, "Keykubadiye Sarayı Kazısı 2015 Yı1ı Seramik Buluntuları”, Akdeniz Üniversitesi Güzel Sanatlar Fakültesi Akdeniz Sanat Dergisi 3/23 (2019), 61-71.

${ }^{64}$ Muharrem Çeken, Hasankeyf (1991, 2001, 2003 Yılı) Kazı Buluntusu Fırın ve Atölyeleri ile Seramik Malzemeleri (Ankara: Ankara Üniversitesi, Sosyal Bilimler Üniversitesi, Doktora Tezi, 2005), 395-411.

${ }^{65}$ Türe, Ayasuluk Kalesi Doğu Kapısı Çevresindeki 2000-2002 Kurtarma Kazllarında Ele Geçen Seramikler, 152-253.

${ }^{66}$ Muradiye Bursalı, Eskişehir Karacahisar Kalesi Sigrafitto Dekorlu Ortaçă̆ Seramikleri (Eskişehir: Eskişehir Anadolu Üniversitesi, Sosyal Bilimler Enstitüsü, Yüksek Lisan Tezi, 2007), 50-140.

${ }^{67}$ Nurşen Özkul Fındık, İznik Roma Tiyatrosu Kazısı Seramik Buluntuları (Ankara: Hacettepe Üniversitesi, Sosyal Bilimler Enstitüsü, Doktora Tezi, 2000), 71, 112, 138.

${ }^{68}$ Sevinç Gök Gürhan, “Beylikler Dönemi’ne Ait Sigrafitto Teknikli ve Tek Renk Sırlı Kaplar, Ege Üniversitesi Sanat Tarihi Dergisi 17 (Ekim 2008), 59-83.

${ }^{69}$ Necla Dursun, "Konya Karatay (Çini Eserler) Müzesindeki Kazıma ve Sigrafitto Seramikler”, 2. Uluslararası Avrasya Türk Sanatları Kongresi, ed. J. Özlem Oktay Çerezci - Halenur Katipoğlu (İstanbul: Mimar Sinan Güzel Sanatlar Üniversitesi Yayınları, 2018), 201-214.

${ }^{70}$ Muharrem Çeken, "Kubad Abad Sarayı Selçuklu Dönemi Seramik Buluntuları”, Beyşehir Gölü Kıyısında Bir Selçuklu Sitesi: Kubad Abad (Konya: Konya Büyükşehir Belediyesi Kültür Yayınları, 2019), 283-334.
} 


\section{KAYNAKÇA}

Ağatekin, Mustafa. Selçuklu Dönemi Seramik Yüzeylerinde Insan Betimlemeleri. Eskişehir: Anadolu Üniversitesi, Sosyal Bilimler Enstitüsü, Sanatta Yeterlilik Tezi 2003.

Anılmert, Beril - Rona, Zeynep, “Seramik”. Eczacıbaşı Sanat Ansiklopedisi. ed. Nejat F. Eczacıbaşı. 3/16341641. İstanbul: Yem Yayınları, 1997.

Aslan Böhlendorf, Beate, "Die Beziehungen Zwischen Byzantinischer Und Emiratszeitlicher Keramik", Ortaçağda Anadolu Prof. Dr. Aynur Durukan'a Armağan, ed. N. Şaman Doğan. 135-156. Ankara: Hacettepe Üniversitesi Yayınları, 2002.

Aşıkpaşazade, Asşık Paşaoğlu Tarihi. haz. N. Atsız. İstanbul: Milli Eğitim Bakanlığı Yayınları, 1992.

Atçeken, Zeki. “Karamanoğulları'na Kadar Konya'nın Kısa Tarihi”. Yeni İpek Yolu Dergisi, (Hz. Mevlânâ'nın 728. Vuslat Yıldönümü Anısına Özel Sayı). ed. Yusuf Küçükdağ, 65-70. Konya: Konya Ticaret Odası Yayınevi, 2001.

Atçeken, Zeki. Konya'daki Selçuklu Yapılarının Osmanlı Devrinde Bakımı ve Kullanılması. Ankara: Türk Tarih Kurumu, 1998

Avşar, Mezahir Ertuğ - Avşar Lale, Kazımalı-Akıtmalı Ortaçă̆ İslâm Seramikleri. Konya: Selçuk Üniversitesi Basımevi, 2014.

Ayaönü, Yusuf. "Selçuklu-Bizans İlişkileri”. Türkler. ed. Hasan Celal Güzel vd. 6/595-599. Ankara: Yeni Türkiye Yayınları, 2002.

Aygör, Erkan. "Konya Gevale Kalesi 2016 Yı1ı Kazısında Bulunan Ok Uçları”, Türkiyat Araştırmaları Enstitüsü Dergisi 7 (Nisan 2017), 284-306.

Bahar, Hasan, "Takkeli Dağ (Kevele Kalesi) ve Konya Tarihi Bakımından Önemi”, S.Ü. Sosyal Bilimler Enstitüsü Dergisi 3 (1994), 313-333.

Baş, Ali - Dursun, Şükrü. "Keykubadiye Sarayı Kazısı 2015 Yılı Seramik Buluntuları”. Akdeniz Üniversitesi Güzel Sanatlar Fakültesi Akdeniz Sanat Dergisi 23/3 (Temmuz 2019), 57-77.

Baykara, Tuncer. Türkiye Selçukluları Devrinde Konya. Konya: Kültür ve Turizm Bakanlığı Yayınları, 1985.

Bilici, Sema. "Alanya-Selçuklu Sarayı Seramikleri”, Uluslararası Sanat Tarihi Sempozyumu Prof. Dr. Gönül Öney'e Armağan (İzmir: Ege Üniversitesi Yayınları, 2002), 139-154.

Bilici, Sema. Akdeniz Bölgesi Örneklerine Göre Ortaçă̆ Anadolu Sigrafitto Seramiklerine Materyal, Biçim, Teknik ve Stilistik Açıdan Bir Yaklaşım Tarihleme ve Bir Tipoloji Denemesi. Ankara: Ankara Üniversitesi, Sosyal Bilimler Enstitüsü, Doktora Tezi, 1992.

Bursalı, Muradiye. Eskişehir Karacahisar Kalesi Sigrafitto Dekorlu Ortaçağ Seramikleri. Eskişehir: Eskişehir Anadolu Üniversitesi, Sosyal Bilimler Enstitüsü, Yüksek Lisans Tezi, 2007.

Çaycı, Ahmet - Şimşir, Zekeriya. "2015 Yılı Gevale Kalesi Arkeolojik Kazısı". Uluslararası XX Ortaçağ ve Türk Dönemi Kazıları ve Sanat Tarihi Araştırmaları Sempozyumu (Sakarya 2-5 Kasım 2016). 1/37-48. Sakarya: Sakarya Üniversitesi Yayınları, 2017.

Çaycı, Ahmet - Şimşir, Zekeriya. "Gevale Kalesi 2013-2014 Kazı Buluntuları". 37. Uluslararası Kazı, Araştırma ve Arkeometri Sempozyumu. ed. Adil Özme. 3/539-558. Ankara: Kültür ve Turizm Bakanlı̆̆ı Yayınları, 2016.

Çaycı, Ahmet - Şimşir, Zekeriya. "Gevale Kalesi 2014 Yılı Kazı Çalışmaları”. XXII. Uluslararası Ortaçă̆ ve Türk Dönemi Kazlları ve Sanat Tarihi Araştırmaları Sempozyumu (Manisa 21-24 Ekim 2015). ed. Adil Özme. 1/383-401. Ankara: Kültür ve Turizm Bakanlığı Yayınları, 2019.

Çaycı, Ahmet - Şimşir, Zekeriya. "Gevale Kalesi 2017 Yılı Kazı Çalışmaları”. 40. Uluslararası Kazı, Araştırma ve Arkeometri Sempozyumu (Çanakkale, 7-11 Mayıs 2018). ed. Adil Özme. 1/49-62. Ankara: Kültür ve Turizm Bakanlığı Yayınları, 2019.

Çaycı, Ahmet - Şimşir, Zekeriya. "Gevale Kalesi 2018 Yılı Kazı Çalışmaları”. 41. Uluslararası Kazı, Araştırma ve Arkeometri Sempozyumu (Diyarbakır, 17-21 Haziran 2019). ed. Adil Özme. 1/67-77. Ankara: Kültür ve Turizm Bakanlığı Yayınları, 2020.

Çaycı, Ahmet - Şimşir, Zekeriya - Mimiroğlu, İ. Mete. "Gevale Kalesi ve Çevresi Araştırmaları”. 31. Araştırma Sonuçları Toplantısı (Muğla 27-31 Mayıs 2013). ed. Adil Özme. 1/276-286. Ankara: Kültür ve Turizm Bakanlığı Yayınları, 2014.

Çeken, Muharrem. "Kubad Abad Sarayı Selçuklu Dönemi Seramik Buluntuları”. Beyşehir Gölü Kıyısında Bir Selçuklu Sitesi. Kubad Abad. ed. Alptekin Yavaş - Oğuz Koçyiğit. 283-334. Konya: Konya Büyükşehir Belediyesi Kültür Yayınları, 2019.

Çeken, Muharrem. "Kubad Abad Sarayı Selçuklu Seramikleri”. Anadolu Türk Devri Çini ve Seramik Sanatı. ed. Gönül Öney, Zehra Çobanlı. 469-488. İstanbul: Kültür ve Turizm Bakanlığı Yayınları, 2007.

Çeken, Muharrem. Hasankeyf (1991, 2001, 2003 Yılı) Kazl Buluntusu Fırın ve Atölyeleri ile Seramik Malzemeleri. Ankara: Ankara Üniversitesi, Sosyal Bilimler Üniversitesi, Doktora Tezi, 2005.

Darkot, Besim. "Konya”. Türkiye Diyanet Vakfi İslâm Ansiklopedisi. 6/841-850. İstanbul: Türkiye Diyanet Vakfı Yayınları, 1977. 
Dursun, Necla. “Konya Karatay (Çini Eserler) Müzesindeki Kazıma ve Sigrafitto Seramikler”. 2. Uluslararası Avrasya Türk Sanatları Kongresi. ed. J. Özlem Oktay - Halenur Katipoğlu. 201-214. İstanbul: Mimar Sinan Güzel Sanatlar Yayınevi, 2014.

Erdoğan, Muzaffer. “Osmanlı Devrinde Anadolu Camilerinde Restorasyon Faaliyetleri”. Vakıflar Dergisi 7/149205. İstanbul: Baha Matbaas1. 1968.

Ermiş, Gülistan. Gevale Kalesi Kazılarında Bulunan Íslami Dönem Sikkeler. Konya: Necmettin Erbakan Üniversitesi, Sosyal Bilimler Enstitüsü, Yüksek Lisans Tezi, 2019.

Fındık, Nurşen Özkul. İznik Roma Tiyatrosu Kazısı Seramik Buluntuları. Ankara: Hacettepe Üniversitesi, Sosyal Bilimler Enstitüsü, Doktora Tezi, 2000.

Fikret Hacızade, "Seramik Alanında Kullanılan Terim ve Kavramlarda Türkçenin Durumu”, Türkiyat Araştırmaları Dergisi, ed. Hakan Kuyumcu - Çağatay Benhür. 39-54. Konya: Selçuk Üniversitesi Yayınları, 2014.

Gök, Gürhan Sevinç. Akşehir Taş Medrese Müzesindeki Türk Dönemi Seramikleri. İzmir: Ege Üniversitesi, Sosyal Bilimler Enstitüsü, Doktora Tezi, 2007.

Gürhan, Sevinç Gök. “Beylikler Dönemi’ne Ait Sigrafitto Teknikli ve Tek Renk Sırlı Kaplar, Ege Üniversitesi Sanat Tarihi Dergisi 17 (Ekim 2008), 59-83.

Hoca Sadeddin Efendi. Tacü't-Tevârih. çev. İsmet Parmaksızoğlu. 1 Cilt. Ankara: Kültür Bakanlığı Yayınları, 1979.

Huart, C. Mevleviler Beldesi Konya. çev. N. Uzel. İstanbul: Kervan Kitapçılık Basımevi, 1978.

İbn Bibi, El-Evâmirü'l-Alâ'iyefi'l-Umûri'l-Alâ'iye (Selçuknâme). haz. Mürsel Öztürk. 1-2 Cilt. Ankara: Türk Tarih Kurumu, 1996.

Karamağaralı, Nakış. “Ahlat Sırlı Seramikleri”. ed. Gönül Öney - Zehra Çobanlı. 135-153. Anadolu'da Türk Devri Çini ve Seramik Sanatı. İstanbul: Kültür ve Turizm bakanlığı Yayınları, 2007.

Karauğuz, Güngör - Kunt, H. İbrahim. Eski Çağ Kaleleri -Orta Anadolu’nun Güney Kesimi. Konya: Çizgi Kitabevi, 2004.

Kesik, M. “Sultan Melikşah (Şahinşah) ve Sultan I. Mesud Dönemleri”. Türkler. ed. Hasan Celal Güzel vd. 6/7477. Ankara: Yeni Türkiye Yayınları, 2002.

Konyalı, İ. Hakkı. “Takkeli Dağ Adını Nerden Aldı”. Konya Halkevi Dergisi 12 (2 Kanun 1937), 765-768.

Konyalı, İ. Hakk1. Âbideleri ve Kitâbeleri ile Karaman Tarihi Ermenek ve Mut Âbideleri. İstanbul: Baha Maatbas1, 1967.

Konyalı, İ. Hakk1. Abideleri ve Kitabeleri ile Konya Tarihi. Konya: Yeni Kitap Basımevi. 1964.

Konyalı, İ. Hakkı. Nasreddin Hoca'nın Şehri Akşehir Tariĥ̂- Turistik Kılavuz. İstanbul: Numune Matbaası Yayınlar1, 1945.

Küçükdağ, Yusuf - Arabacı, Caner. Selçuklular ve Konya. Konya: Mikro Yayınları, 1999.

Merçil, Erdoğan. Müslüman-Türk Devletleri Tarihi. Ankara: Türk Tarih Kurumu, 1993.

Odabaşı, A. Sefa. 20. Yüzyıl Başlarında Konya'nın Görünümü. Konya: Konya Valiliği İl Kültür Müdürlüğü Yayınlar1, 1998.

Oral, M. Zeki. "Fatih Sultan Mehmet'in Gevale Kalesi ile Karaman İllerini Fethi ve Hamîdî'nin Terci-i Bendi”, Vakıflar Dergisi 4 (1958), 81-90.

Öden, Z. Günal. "Karamanoğulları Beyliği”. Türkler. ed. Hasan Celal Güzel vd. 6/756-762. Ankara: Yeni Türkiye Yayınları, 2002.

Önder, Mehmet. Gez Dünyayı Gör Konya'yı. Konya: Konya Büyükşehir Belediyesi Yayınları, 1999.

Önder, Mehmet. Mevlâna Şehri Konya. Ankara: Konya Turizm Derneği Yayınları,1971.

Öney, Gönül. "Selçuklu Seramik Sanatı”. Selçuklu Çă̆ında Anadolu Sanatı. ed. Doğan Kuban. 385-390. İstanbul: Yapı Kredi Yayınları, 2002.

Özcan, Zehra. Konya Zindankale (Ahmedek) Kazı ve Buluntuları. Çanakkale: Çanakkale Onsekiz Mart Üniversitesi, Sosyal Bilimler Enstitüsü, Yüksek Lisan Tezi, 2019.

Özdeniz, H. Hüseyin. Gevale Kalesi Kazllarında Bulunan Ortaçă̆ Seramikleri. Konya: Necmettin Erbakan Üniversitesi, Sosyal Bilimler Enstitüsü, Yüksek Lisans Tezi, 2019.

Özönder, Hasan. Sille (Tarih-Kültür-Sanat). Konya: 1998.

Öztaşkın, Muradiye. "Proposal for Terminology of Byzantine Pottery Forms". XI. Alecm3 Uluslararası Orta Çăg ve Modern Akdeniz Dünyası Seramik Kongresi Bildirileri 1 (Ekim 2015), 331-338.

Polat, Turgay. "Milet İşi Seramiklerde Form Tipolojisi Üzerine Bir Deneme". Sanat Tarihi Dergisi 25 (Ekim 2016). 213-247.

Sarıköse, Barış. Osmanlı Döneminde Sille. Konya: Çizgi Kitabevi Yayınları, 2008.

Sevim, Ali - Merçil, Erdoğan. Selçuklu Devletleri Tarihi Siyaset, Teşkilât ve Kültür. Ankara: Türk Tarih Kurumu, 1995.

Sevim, Sidıka Sevim. Seramik Dekor ve Uygulama Teknikleri. İstanbul: Nobel Akademik Yayınları, 2007. Sözen, Metin. Tanyeli, Uğur. Sanat Kavram ve Terimleri Sözlüğü. İstanbul: Remzi Kitabevi Yayınları, 1992. 
Şahin, Faruk. Seramik Sözlüğü. İstanbul: Anadolu Sanat Yayınları, 1983.

Şen, Ahmet. "Konya Gevale Kalesi Kazılarında Bulunan Taş Gülleler (2013-2016)". Selçuklu Medeniyeti Araştırmaları Dergisi (SEMA) 4 (Aralık 2019). 189-224.

Şikarî, Karamannâme (Zamanın Kahramanı Karamanîler'in Tarihi). haz. Metin Sözen - Necdet Sakaoğlu. İstanbul: Karaman Valiliği Yayınları 2005.

Şimşirgil, Ahmet. "Eşrefoğulları Beyliği”. Türkler. ed. Hasan Celal Güzel vd. 6/74-77. Ankara: Yeni Türkiye Yayınları, 2002.

Turan, Osman. Selçuklular Zamanında Türkiye. İstanbul. Ötüken Yayınları, 1998.

Turgal, H. F. “Konya Tarihinin Mühim Bir Safhası Muhtasar İbn Bibiye Göre Cimri Vak'ası”. Konya Halkevi Dergisi 3 (2 Teşrin 1936), 152-162

Tülek, Füsun. "Identifying Osmaniye Medieval Ceramics in Multi-Cultural Context". XI. Alecm3 Uluslararasl Orta Çă̆ ve Modern Akdeniz Dünyası Seramik Kongresi Bildirileri 1 (Ekim 2015), 363-369.

Türe, Sevcan. Ayasuluk Kalesi Doğu Kapısı Çevresindeki 2000-2002 Kurtarma Kazllarında Ele Geçen Seramikler. Edirne: Trakya Üniversitesi, Sosyal Bilimler Enstitüsü, Yüksek Lisan Tezi, 2014.

Uğur, M. Ferit. “Takkeli Dağ”. Konya Halkevi Dergisi 5 (2 Kanun 1937), 299-303.

Uzunçarşıll, İ. Hakkı. Anadolu Beylikleri ve Akkoyunlular, Karakoyunlu Devletleri. Ankara: Türk Tarih Kurumu, 1988.

Uzunçarşılı, İ. Hakkı. Osmanlı Tarihi. 1. Cilt. Ankara: Türk Tarih Kurumu, 1972.

Ünal, Tahsin . "Karaman Oğlu Mehmet Bey”, Anıt 10 (Kasım Konya), 1949.

Ünal, Tahsin. Karamanoğulları Tarihi. Konya: Karaman Esnaf ve Kefalet Kooperatifi Yayınları. 1986.

Yardımcı, Melih. Şavşat Kalesi Kazısı Sırlı ve Sırsız Seramik Buluntularının Değerlendirilmesi. Van: Yüzüncü Y1l Üniversitesi, Sosyal Bilimler Enstitüsü. Yüksek Lisan Tezi, 2015.

Yardımıı, Melih. Şavşat Kalesi Kazısı Sırlı ve Sırsız Seramik Buluntuların Değerlendirilmesi. Van: Yüzüncü Yı1 Üniversitesi, Sosyal Bilimler Enstitüsü, Yüksek Lisan Tezi, 2015.

Yavuzyılmaz, Ahmet. "Gevale Kalesi Cam Bilezik Buluntuları”. XX. Uluslararası Ortaçağ ve Türk Dönemi Kazıları ve Sanat Tarihi Araştırmaları Sempozyumu Bildirileri. 1 Cilt. (Temmuz 2017), 49-61.

Yinanç, M. Halil. “Anadolu'nun Fethi”. Türkler. ed. Hasan Celal Güzel vd. 6/107-116. Ankara: Yeni Türkiye Yayınlar1, 2002. 